\title{
Effect of Saccharomyces cerevisiae fermentation product on feed intake parameters, lactation performance, and metabolism of transition dairy cattle
}

\author{
K. E. Olagaray, ${ }^{1}$ S. E. Sivinski, ${ }^{1}$ B. A. Saylor, ${ }^{1}$ L. K. Mamedova, ${ }^{1}$ J. A. Sauls-Hiesterman, ${ }^{1}$ I. Yoon, ${ }^{2}$ \\ and B. J. Bradford ${ }^{1 *}$ \\ ${ }^{1}$ Department of Animal Sciences and Industry, Kansas State University, Manhattan 66506 \\ 2'Diamond V, Cedar Rapids, IA 74570
}

\section{ABSTRACT}

The transition period in dairy cattle is characterized by many stressors, including an abrupt diet change, but yeast product supplementation can alter the rumen environment to increase dairy cattle productivity. Saccharomyces cerevisiae fermentation product (SCFP) was fed from $-29 \pm 5$ to $42 \mathrm{~d}$ relative to calving (RTC) to evaluate the effects on feed intake, milk production, and metabolism. Treatments were control $(\mathrm{n}=30)$ or SCFP ( $\mathrm{n}=34$ ) incorporated into a total mixed ration. Cows were individually fed $3 \times / \mathrm{d}$ prepartum and $2 \times /$ d postpartum. Blood samples were collected once during each of the following time points RTC: $\mathrm{d}-28$ to -24 (wk -4$), \mathrm{d}-14$ to -10 (wk -2$)$, d 3 to 7 (wk 1), d 12 to 16 (wk 2), and d 31 to 35 (wk 5). Liver biopsies were taken once between $\mathrm{d}-19$ and $\mathrm{d}$ $-12(\mathrm{wk}-3)$ and at $14 \mathrm{~d}$ in milk. Cows were milked $2 \times / \mathrm{d}$, and samples were taken $2 \mathrm{~d} /$ wk for composition analysis. Dry matter intake did not differ by treatment, but SCFP increased meals per day and decreased time between meals. Body weight (measured at enrollment, d 0, and d 42 RTC) and body condition score (scored weekly) were not affected by treatment. Milk, energycorrected milk, and fat-corrected milk yields did not differ by treatment. Milk fat concentration was greater for SCFP, with significant differences in wk 4 and 5 . Milk lactose concentration tended to be greater for the control and milk urea nitrogen tended to be lesser for the control, but there were no treatment effects on milk protein concentration or somatic cell count. Assuming equal digestibility, energy balance deficit was greater for SCFP than for the control ( -6.15 vs. $-4.34 \pm 0.74 \mathrm{Mcal} / \mathrm{d}$ ), with significant differences in wk 4 and 5. Plasma concentrations of free fatty acids, $\beta$-hydroxybutyrate, glucose, and insulin did not differ with treatment, but cholesterol was greater for

Received January 16, 2019.

Accepted May 14, 2019.

*Corresponding author: bbradfor@ksu.edu
SCFP. Liver triglyceride increased and liver cholesterol decreased with time. Liver triglyceride did not differ by treatment, but liver cholesterol tended to be lesser in SCFP. Relative mRNA abundance of cholesterolrelated genes (SREBF2, HMGCS1, HMGCR, MTTP, SPOB100, APOA1), FGF21, and CPT1A did not differ by treatment, but $P C K 1$ tended to be greater for SCFP. The ketogenic transcript HMGCS2 was greater for SCFP, which aligns with SCFP increasing incidence of subclinical ketosis; however, $B D H$ did not differ between treatments. In conclusion, SCFP supplementation increased meals per day with less time between meals, increased milk fat concentration, altered cholesterol metabolism, and increased incidence of subclinical ketosis, but early-lactation milk yield and metabolism were generally unaffected.

Key words: Saccharomyces cerevisiae fermentation product, transition cow, feeding behavior

\section{INTRODUCTION}

Feeding yeast culture products to dairy cattle can alter the rumen environment to increase populations of microbes associated with fiber digestion (Mullins et al., 2013), increase lactic acid utilization, and increase ruminal $\mathrm{pH}$ (Piva et al., 1993). Milk production responses have been variable, with reports of increased milk production in some studies (Zaworski et al., 2014; Acharya et al., 2017; Dias et al., 2018a) but not others (Dann et al., 2000; Schingoethe et al., 2004; Yuan et al., 2015a). Possible explanations for varying production responses to Saccharomyces cerevisiae fermentation product (SCFP) include differences in dietary NDF concentration (Robinson and Erasmus, 2009), forage: concentrate ratio (Piva et al., 1993), DMI and level of milk production (Allen and Ying, 2012), and stage of lactation (Poppy et al., 2012) across studies.

Saccharomyces cerevisiae fermentation products have been particularly advantageous during periods of stress, reducing fluctuations in rumen $\mathrm{pH}$ during SARA ( $\mathrm{Li}$ et al., 2016) and increasing DMI during the transition pe- 
riod (3 wk before and after calving; Poppy et al., 2012). The meta-analysis by Poppy et al. (2012) determined that early-lactation SCFP supplementation increased DMI by $0.62 \mathrm{~kg} / \mathrm{d}$ and ECM by $1.65 \mathrm{~kg} / \mathrm{d}$. Mechanisms behind these responses to SCFP supplementation during the transition period are not fully known but could be attributed to altered rumen microbial population and thus changes in ruminal VFA production (Poppy et al., 2012), altered feeding behavior (DeVries and Chevaux, 2014; Yuan et al., 2015a), or improved immune function (Zaworski et al., 2014).

The SCFP evaluated in this study is a new product that contains added antioxidants and polyphenols. Based on previous SCFP studies and the anti-inflammatory and antioxidant effects of polyphenols (Middleton et al., 2000), we hypothesized that feeding this SCFP product during the transition period would alter feeding behavior. The primary objective of this study was to determine the effect of this new SCFP product (NutriTek, Diamond V, Cedar Rapids, IA) on feeding behavior during the transition period in dairy cows; the secondary objective was to evaluate the effects on milk production and composition, energy balance, and metabolism.

\section{MATERIALS AND METHODS}

Experimental procedures were approved by the Kansas State University Institutional Animal Care and Use Committee (protocol no. 3759.2).

\section{Cows and Treatments}

Sixty-four prepartum Holstein cows (50 multiparous, 14 primiparous) were used in a randomized complete block design. Cows were blocked by parity, expected calving date, and previous 305-d ME yield and then randomly assigned to treatment within block. Treatments were either control $(\mathrm{n}=30)$ or SCFP $(16.0 \pm$ $0.7 \mathrm{~g} / \mathrm{d}$ prepartum and $18.9 \pm 0.5 \mathrm{~g} / \mathrm{d}$ postpartum; $\mathrm{n}=$ 34; NutriTek, Diamond V) incorporated into a TMR. The TMR was formulated for an expected average DMI of $11.1 \mathrm{~kg} / \mathrm{d}$ prepartum and $20 \mathrm{~kg} / \mathrm{d}$ postpartum. Differences between expected and observed intakes resulted in slight deviations from the manufacturer's recommended SCFP dose of $19 \mathrm{~g} / \mathrm{d}$. Across the entire period, SCFP consumption averaged $17.4 \pm 0.6 \mathrm{~g} / \mathrm{d}$. We evaluated the power of the study to detect difference in Ig response to ovalbumin vaccination, our key measure of adaptive immune function (results not shown here). We used variance data from our past work (Yuan et al., 2015b) and found that 60 cows (30/treatment) would provide $90 \%$ power to detect a 0.06 difference in optical density for anti-ovalbumin IgG. This magnitude matches the difference in means observed in our previous study (Yuan et al., 2015b) and at 15\% of the mean optical density reflects sufficient sensitivity to detect a meaningful difference in antibody production. Treatments were fed from $-29 \pm 5$ to $42 \mathrm{~d}$ relative to calving (RTC). Time points referencing time RTC refer to days before expected calving date for prepartum data and days relative to actual calving date for postpartum data. Average BCS (3.61 \pm 0.06$)$ and BW $(689 \pm 13 \mathrm{~kg})$ were not different between treatment groups at enrollment $(P \geq 0.41)$.

Diets were formulated to meet NRC (2001) requirements for a $650-\mathrm{kg}$ Holstein cow; the lactation diet was formulated to support $45 \mathrm{~kg}$ of milk production/d at 20 $\mathrm{kg}$ of DMI/d. Feed ingredient samples were collected once weekly, composited by 4 mo (12-mo experiment), and analyzed by wet chemistry methods for DM, NDF, starch, CP, ether extract, and ash content (Dairy One, Ithaca, NY). Dry matter content was determined by oven drying for $3 \mathrm{~h}$ at $105^{\circ} \mathrm{C}$. Crude protein was determined (Etheridge et al., 1998) by oxidation and detection of $\mathrm{N}_{2}$ (Leco Analyzer, Leco Corp., St. Joseph, MI). Concentrations of ash-free NDF and ADF (Van Soest et al., 1991) were determined using an Ankom Fiber Analyzer (Ankom Technology, Macedon, NY) and filter bags with a pore size of $25 \mu \mathrm{m}$. Sodium sulfite was added to the detergent solution for the ash-free NDF analysis. Crude fat was determined by ether extraction (method 2003.05; AOAC International, 2012). Ash concentration was determined using AOAC International (2012) method 942.05. Chemical analyses of individual feed ingredients were used for determination of TMR nutrient composition (Table 1).

To evaluate adaptive immunity, cows were injected on d 7 and 21 RTC with an innocuous protein, ovalbumin (0.5 mg; Sigma-Aldrich, St. Louis, MO) along with $0.25 \mathrm{mg}$ of Quil-A adjuvant dissolved in $1.0 \mathrm{~mL}$ of saline (vac-quil; Invivogen, San Diego, CA). Results for this protocol are not presented here.

\section{Data and Sample Collection}

Prepartum cows were fed treatment diets $3 \times / \mathrm{d}$ (0900, 1300, and $1700 \mathrm{~h})$ using an electronically gated feeding system (Roughage Intake System; Insentec B.V., Marknesse, the Netherlands). All cows on a given dietary treatment were allowed access to 4 feed bins assigned to that treatment, and no more than 6 animals shared those 4 bins at any given time. After calving, cows were moved to a tiestall facility where they were fed individually twice daily (0500 and $1700 \mathrm{~h}$ ). Both feeding systems electronically recorded individual feed consumption and meal patterns. As-fed feed intake was recorded daily and adjusted by TMR DM for determi- 
nation of meal and daily DMI. Analysis of individual feeding behavior data was performed according to Yuan et al. (2015a). Specifications for feeding behavior parameters such as a minimum intermeal interval of 12 min and minimum meal weight of $0.4 \mathrm{~kg}$ were based on Mullins et al. (2012). Meals considered biologically infeasible (eating rate $>1.8 \mathrm{~kg} / \mathrm{min}$ ) were removed before analysis of meal weight, length, and count. In addition to electronically recorded DMI determination, feed refusals and water intake were measured daily postpartum.

Cows were milked $2 \times / \mathrm{d}(0400$ and $1600 \mathrm{~h})$ and milk weights were recorded at each milking. Milk samples were collected at each milking $2 \mathrm{~d} /$ wk and analyzed

Table 1. Ingredient and nutritional composition (\% of DM unless otherwise noted) of the prepartum and postpartum diets

\begin{tabular}{|c|c|c|c|c|}
\hline \multirow[b]{2}{*}{ Item } & \multicolumn{2}{|c|}{ Prepartum } & \multicolumn{2}{|c|}{ Postpartum } \\
\hline & Control & $\mathrm{SCFP}^{1}$ & Control & SCFP \\
\hline \multicolumn{5}{|l|}{ Ingredient } \\
\hline Lower quality alfalfa hay $(22.1 \% \mathrm{CP})$ & \multicolumn{2}{|c|}{ - } & \multicolumn{2}{|c|}{9.57} \\
\hline Higher quality alfalfa hay $(23.9 \% \mathrm{CP})$ & \multicolumn{2}{|c|}{ - } & \multicolumn{2}{|c|}{9.57} \\
\hline Grass hay & \multicolumn{2}{|c|}{38.61} & \multicolumn{2}{|c|}{1.66} \\
\hline Corn silage & \multicolumn{2}{|c|}{21.15} & \multicolumn{2}{|c|}{24.06} \\
\hline Wet corn gluten feed ${ }^{2}$ & \multicolumn{2}{|c|}{18.09} & \multicolumn{2}{|c|}{23.56} \\
\hline Cottonseed & \multicolumn{2}{|c|}{ - } & \multicolumn{2}{|c|}{3.98} \\
\hline Ground corn & 7.73 & 7.69 & 17.16 & 17.11 \\
\hline Micronutrient premix ${ }^{3,4,5,6}$ & 14.42 & 14.48 & 10.42 & 10.48 \\
\hline \multicolumn{5}{|l|}{ Nutrient } \\
\hline $\mathrm{DM}, \%$ as fed & \multicolumn{2}{|c|}{63.3} & \multicolumn{2}{|c|}{59.7} \\
\hline $\mathrm{CP}$ & \multicolumn{2}{|c|}{12.9} & \multicolumn{2}{|c|}{17.0} \\
\hline $\mathrm{ADF}$ & \multicolumn{2}{|c|}{25.0} & \multicolumn{2}{|c|}{17.8} \\
\hline Ash-free NDF & \multicolumn{2}{|c|}{43.1} & \multicolumn{2}{|c|}{31.3} \\
\hline NFC & \multicolumn{2}{|c|}{30.1} & \multicolumn{2}{|c|}{37.6} \\
\hline Starch & \multicolumn{2}{|c|}{15.3} & \multicolumn{2}{|c|}{22.6} \\
\hline Crude fat & \multicolumn{2}{|c|}{5.1} & \multicolumn{2}{|c|}{6.3} \\
\hline $\mathrm{NE}_{\mathrm{L}},{ }^{7} \mathrm{Mcal} / \mathrm{kg}$ & \multicolumn{2}{|c|}{1.42} & \multicolumn{2}{|c|}{1.66} \\
\hline
\end{tabular}

${ }^{1}$ Saccharomyces cerevisiae fermentation product.

${ }^{2}$ Sweet Bran (Cargill Inc., Blair, NE).

${ }^{3}$ Prepartum control micronutrient premix consisted of $37.5 \%$ SoyChlor (anionic feed supplement, West Central Cooperative, Ralston, IA), $34.3 \%$ soybean meal, $7.51 \%$ calcium propionate, $6.44 \%$ calcium sulfate, $5.36 \% \mathrm{Ca}$ salts of long-chain fatty acids (Megalac R, Arm \& Hammer Animal Nutrition, Princeton, NJ), 2.68\% Reashure ( $28.8 \%$ choline chloride, Balchem Corp., New Hampton, NY), $2.14 \%$ vitamin E (20 kIU/g), 1.29\% stock salt, 1.03\% Niashure (65\% niacin, Balchem Corp.), 0.54\% magnesium oxide, 0.33\% 4-Plex (Zinpro Corp., Eden Prairie, MN), 0.21\% vitamin A premix (30 kIU/g), 0.19\% selenium, 0.15\% Zinpro 120 (Zinpro Corp.), 0.10\% Rumensin 90 (Elanco Animal Health, Greenfield, IN), 0.09\% Biotin 100 (ADM Alliance Nutrition, Quincy, IL), $0.06 \%$ vitamin D premix (30 kIU/g), and $0.02 \%$ ethylenediamine dihydroiodide premix $(3.65 \% \mathrm{I})$.

${ }^{4}$ Prepartum SCFP micronutrient premix consisted of 37.2\% SoyChlor (anionic feed supplement, West Central Cooperative), $34.0 \%$ soybean meal, $7.44 \%$ calcium propionate, $6.37 \%$ calcium sulfate, $5.31 \%$ Ca salts of longchain fatty acids (Megalac R, Arm \& Hammer Animal Nutrition), 2.66\% Reashure $(28.8 \%$ choline chloride, Balchem Corp.), $2.12 \%$ vitamin E (20 kIU/g), 1.27\% stock salt, 1.02\% Niashure (65\% niacin, Balchem Corp.), 0.94\% SCFP (NutriTek, Diamond V. Cedar Rapids, IA), 0.53\% magnesium oxide, 0.33\% 4-Plex (Zinpro Corp.), $0.21 \%$ vitamin A premix (30 kIU/g), 0.19\% selenium, 0.15\% Zinpro 120 (Zinpro Corp.), 0.10\% Rumensin 90 (Elanco Animal Health), 0.09\% Biotin 100 (ADM Alliance Nutrition), 0.06\% vitamin D premix (30 kIU/g), and $0.02 \%$ ethylenediamine dihydroiodide premix $(3.65 \% \mathrm{I})$.

${ }^{5}$ Postpartum control micronutrient premix consisted of $59.9 \%$ expeller soybean meal (SoyBest, Grain States Soya, West Point, NE), $12.0 \%$ limestone, $10.5 \%$ sodium bicarbonate, $7.48 \%$ Ca salts of long-chain fatty acids (Megalac R, Arm \& Hammer Animal Nutrition), 2.40\% magnesium oxide, $1.50 \%$ stock salt, $1.50 \%$ trace mineral salt, $1.50 \%$ potassium chloride, $1.50 \%$ vitamin E (20 kIU $/ \mathrm{g}), 0.94 \%$ Biotin 100 (ADM Alliance Nutrition), $0.25 \%$ selenium premix $(0.06 \%), 0.23 \%$ 4-Plex (Zinpro Corp.), $0.15 \%$ vitamin A premix (30 kIU/g), $0.12 \%$ Zinpro 120 (Zinpro Corp.), 0.06\% Rumensin 90 (Elanco Animal Health), 0.04\% vitamin D premix (30 kIU/g), and $0.01 \%$ ethylenediamine dihydroiodide premix (3.65\% I).

${ }^{6}$ Postpartum SCFP micronutrient premix consisted of 59.4\% expeller soybean meal (SoyBest, Grain States Soya), $11.9 \%$ limestone, $10.4 \%$ sodium bicarbonate, $7.42 \%$ Ca salts of long-chain fatty acids (Megalac R, Arm \& Hammer Animal Nutrition), 2.37\% magnesium oxide, 1.48\% stock salt, $1.48 \%$ trace mineral salt, $1.48 \%$ potassium chloride, $1.48 \%$ vitamin E (20 kIU/g), 0.93\% Biotin 100 (ADM Alliance Nutrition), 0.87\% SCFP (NutriTek, Diamond V), 0.25\% selenium premix (0.06\%), 0.23\% 4-Plex (Zinpro Corp.), $0.15 \%$ vitamin A pre$\operatorname{mix}(30 \mathrm{kIU} / \mathrm{g}), 0.12 \%$ Zinpro 120 (Zinpro Corp.), 0.06\% Rumensin 90 (Elanco Animal Health), 0.04\% vitamin D premix $(30 \mathrm{kIU} / \mathrm{g})$, and $0.01 \%$ ethylenediamine dihydroiodide premix $(3.65 \% \mathrm{I})$.

${ }^{7} \mathrm{NE}_{\mathrm{L}}=0.703 \times \mathrm{ME}(\mathrm{Mcal} / \mathrm{kg})-0.19+\{[0.097 \times \mathrm{ME}(\mathrm{Mcal} / \mathrm{kg})+0.19] / 97\} \times[$ ether extract $(\%)-3]$. 
for concentrations of fat, true protein, lactose (B-2000 Infrared Analyzer; Bentley Instruments, Chaska, MN), MUN (MUN spectrophotometer; Bentley Instruments), and somatic cells (SCC 500; Bentley Instruments) by MQT Labs (Kansas City, MO). Somatic cell linear score (SCLS) was calculated as described by Schukken et al. (2003): SCLS $=\log _{2}[\mathrm{SCC}(1,000$ cells $/ \mathrm{mL}) / 100]+3$. Energy-corrected milk was calculated as $(0.327 \times$ milk yield $)+(12.95 \times$ fat yield $)+(7.65 \times$ protein yield $)$, and FCM was calculated according to NRC (2001) as $(0.432 \times$ milk yield $)+(16.216 \times$ fat yield $)$.

Body condition score was recorded weekly by 3 trained investigators. Body weight was measured at enrollment ( $\mathrm{d}-29 \pm 5 \mathrm{RTC})$, after calving, and at 42 DIM. Prepartum energy balance was calculated according to NRC (2001) as net energy (NE) intake - (NE maintenance $+\mathrm{NE}$ pregnancy), where NE intake is DMI $\times \mathrm{NE}_{\mathrm{L}}$ of prepartum ration, $\mathrm{NE}$ maintenance $(\mathrm{Mcal} / \mathrm{d})$ is $\mathrm{BW}^{0.75} \times 0.08$, and NE for pregnancy $(\mathrm{Mcal} / \mathrm{d})$ is $\{(2 \times 0.00159 \times$ days pregnant -0.0352$) \times[($ mature weight $\times 0.06275) / 45]\} / 0.14$. Postpartum energy balance was calculated as NE intake - (NE maintenance $+\mathrm{NE}$ milk), where NE intake and NE maintenance were calculated as described above but used $\mathrm{NE}_{\mathrm{L}}$ of postpartum diets, and BW was adjusted with a constant weekly rate of BW loss between d 0 and 42 DIM. Net energy in milk was calculated as $0.75 \times$ ECM.

A total of 5 jugular blood samples $(60 \mathrm{~mL})$ were taken from each cow throughout the experiment. The days (RTC) of sampling were as follows: $\mathrm{d}-28$ to -24 (wk -4 ), d -14 to -10 (wk -2 ), d 3 to 7 (wk 1), d 12 to 16 (wk 2), and d 31 to 35 (wk 5). From the 60$\mathrm{mL}$ sample, $50 \mathrm{~mL}$ was used for neutrophil isolation and oxidative burst assay (results not shown), and the remaining $10 \mathrm{~mL}$ was allocated to 2 tubes containing either $\mathrm{K}_{3} \mathrm{EDTA}$ or sodium fluoride. Evacuated containers were immediately placed on ice. Plasma was separated by centrifugation $(1,500 \times g$ for $15 \mathrm{~min})$ and stored in microcentrifuge tubes at $-20^{\circ} \mathrm{C}$ until analyses. Plasma samples were analyzed for free fatty acids (FFA; NEFA-HR; Wako Chemicals USA Inc., Richmond, VA), BHB (kit no. H7587-58; Pointe Scientific Inc., Canton, MI), and glucose (kit no. 439-90901; Wako Chemicals USA Inc.) by enzymatic assays. Insulin was measured by a bovine-specific sandwich ELISA (no. 10-1201-01; Mercodia AB, Uppsala, Sweden). Total plasma cholesterol was measured using a fluorometric assay kit (item no. 10007640; Cayman Chemical, Ann Arbor, MI).

Liver biopsies were collected by percutaneous biopsy according to Mullins et al. (2012) once between d -19 and -12 RTC (allowing prepartum biopsies to occur only $1 \mathrm{~d} / \mathrm{wk}$ ) and at 14 DIM for analysis of transcriptional and metabolic responses to treatment. Liver tissue was immediately frozen in liquid nitrogen. Samples were stored in 1.5-mL microcentrifuge tubes either alone for triglyceride (TG) and cholesterol analysis or with $1 \mathrm{~mL}$ of TriZol (ref. no. 15596018; ThermoFisher Scientific, Waltham, MA) for mRNA analysis; both were stored at $-80^{\circ} \mathrm{C}$ until analysis. Liver TG content was measured as described by Yuan et al. (2013), and cholesterol concentrations were measured using an enzymatic assay (no. ab65390; Abcam, Cambridge, MA). Concentrations are expressed both relative to wet weight and relative to total protein content. Liver total protein concentration was evaluated by the Bradford method using a colorimetric kit (kit no. 23236; Thermo Scientific Pierce, Rockford, IL).

Hepatic transcripts evaluated include fibroblastgrowth factor-21 (FGF21), carnitine palmitoyltransferase 1A $(\boldsymbol{C P T 1 A})$, phosphoenolpyruvate carboxykinase $(\boldsymbol{P C K} \mathbf{1})$, sterol regulatory element binding factor 2 (SREBF2), microsomal TG transfer protein (MTTP), apolipoprotein B 100 (APOB100), 3-hydroxy-3-methylglutaryl-coenzyme A reductase (HMGCR), 3-hydroxy-3-methylglutaryl-coenzyme A synthase 1 (HMGCS1), apolipoprotein A 1 (APOA1), 3-hydroxy-3-methylglutaryl-coenzyme A synthase 2 (HMGCS2), BHB dehydrogenase $(\boldsymbol{B D H})$, and internal control genes $\beta$-actin $(\boldsymbol{A C T B})$ and $40 \mathrm{~S}$ ribosomal protein S15 (RPS15). The RNA was isolated from liver tissue using the Direct-zol RNA mini prep kit (cat. no. r2072; Zymo Research, Irvine, CA). Quantitative real-time PCR was performed as previously described (Yuan et al., 2013). Briefly, $2 \mu \mathrm{g}$ of total RNA per sample was used as a template for the reverse transcriptase reaction using random primers (High-Capacity cDNA RT kit; Bio-Rad Laboratories, Hercules, CA). Quality of RNA (integrity number $=7.62 \pm 0.14$ for a random subset of 12 samples) was verified with an Agilent 2100 Bioanalyzer (Agilent Technologies, Santa Clara, CA). Quantitative real-time PCR was run in duplicate using $5 \%$ of the cDNA product on 96-well plates with 200 $\mathrm{n} M$ of gene-specific primers (Table 2) and SYBR Green master mix (cat. no. 172-5120; BioRad Laboratories). All target genes in samples were normalized against the control genes ACTB and RPS15; cycle threshold (Ct) values of these targets were not affected by treatment $(P \geq 0.40)$. Messenger RNA abundance was calculated as $\left(2 \times\right.$ PCR efficiency) ${ }^{-\Delta \mathrm{Ct}}$ (Pfaffl, 2001), and results were scaled such that the wk -3 control mean equaled 1 for each transcript.

Cow health was evaluated daily by visual inspection, rectal temperature measurement, and assessment of urine acetoacetic acid concentration (KetoCare, TRUEplus; Trividia Health, Fort Lauderdale, FL). Cows were monitored for disorders including subclinical ketosis (SCK), milk fever, displaced abomasum, retained placenta, metritis, and mastitis. Subclinical 
ketosis was defined as urine acetoacetic acid concentration $>40 \mathrm{mg} / \mathrm{dL}$, and other diseases were diagnosed according to the definitions of Kelton et al. (1998). Cows diagnosed with SCK were treated for $3 \mathrm{~d}$ with $300 \mathrm{~mL}$ of propylene glycol (Oral Keto Energel, Aspen Veterinary Resources Ltd., Greely, CO).

\section{Cow Exclusion Criteria and Attrition}

A total of 90 cows were enrolled in the study, but data were used from just 64 cows, 59 of which completed the entire study. Five cows were removed from the study due to periparturient health issues that developed $>4$ DIM $(n=2)$ or because of administration of an initial adjuvant for ovalbumin injection that caused a dramatic febrile response $(\mathrm{n}=3)$; for these cows, all prepartum data were used in analyses. The remaining cows that did not complete the study were removed due to $>15 \%$ consumption of the incorrect diet prepartum, generally by overpowering the pneumatic gates $(\mathrm{n}=$ $13)$, inability to adjust to the feeding system $(\mathrm{n}=1)$, calving with $<14 \mathrm{~d}$ on treatment diets $(\mathrm{n}=3)$, twin calving $(\mathrm{n}=4)$, calving paralysis $(\mathrm{n}=1)$, chronic peri- parturient illness developed $<4$ DIM $(\mathrm{n}=3)$, and death $<4$ DIM $(\mathrm{n}=1)$.

\section{Statistical Analysis}

Results were analyzed using the MIXED procedure of SAS (SAS Institute, Cary, NC). Models included fixed effects of treatment, time, parity, and 2- and 3 -way interactions with treatment and the random effects of block and cow. Interactions with parity were tested and removed from the model when $P>0.20$. Repeated measures within cow were modeled with autoregressive or heterogeneous autoregressive covariance structures when data points were equally spaced, selected based on the least Bayesian information criterion value. Unequally spaced data points (e.g., plasma data) were modeled with spatial power covariance structures. Prepartum data for DMI and feeding behavior were analyzed separately from postpartum data due to the different housing systems used. Milk and DMI data were summarized by week for statistical analysis. Outliers were excluded when the studentized residual exceeded an absolute value of 4 , which represents less than $0.01 \%$

Table 2. Gene primers for quantitative reverse-transcriptase PCR of liver samples

\begin{tabular}{|c|c|c|c|c|}
\hline Trancript $^{1}$ & Primer & Primer sequence $\left(5^{\prime}\right.$ to $\left.3^{\prime}\right)$ & Accession no. ${ }^{2}$ & Efficiency $(\%)$ \\
\hline \multirow[t]{2}{*}{ FGF21 } & Forward & GCCAGGCGTCATTCAGATCT & AC_000175.1 & 92 \\
\hline & Reverse & GAAAGCTGCAGGCTTTGGG & & \\
\hline \multirow{2}{*}{ CPT1A } & Forward & CTTCCCATTCCGCACTTTC & DV820520 & 100 \\
\hline & Reverse & CCATGTCCTTGTAATGAGCCA & & \\
\hline \multirow[t]{2}{*}{$P C K 1$} & Forward & CGAGAGCAAAGAGATACGGTGC & NM_174737.2 & 103 \\
\hline & Reverse & TGACATACATGGTGCGACCCT & & \\
\hline \multirow{2}{*}{ SREBF2 } & Forward & GATGCACAAGTCTGGCGTTC & NM_001205600.1 & 70 \\
\hline & Reverse & GTCGATGCCCTTCAGGAGTT & & \\
\hline \multirow[t]{2}{*}{$H M G C S 1$} & Forward & ACAGTGAGGTGGGTAACTTTGA & NM_001206578.1 & 90 \\
\hline & Reverse & GCTGCTTTCTTGCCTAAACTGT & & \\
\hline \multirow[t]{2}{*}{$H M G C R$} & Forward & GCTGCTGGTCGACCTTTCTA & NM_001105613.1 & 70 \\
\hline & Reverse & TCCCACGAGCAATGTTCTCC & & \\
\hline \multirow[t]{2}{*}{$M T T P$} & Forward & TGGGTGTCACTTCGAAAGCC & NM_001101834.1 & 70 \\
\hline & Reverse & GCTCCAGTTTCTGCCTCGAT & & \\
\hline \multirow[t]{2}{*}{ APOB100 } & Forward & CTGGAGAGTGGAACGGATGC & XM_015473552.1 & 95 \\
\hline & Reverse & GCACGTGGTCTGTCTGATGT & & \\
\hline \multirow[t]{2}{*}{ APOA1 } & Forward & GGAGAGCCTCAAGGTCAGCATC & NM_174242.3 & 73 \\
\hline & Reverse & ATCTCACTGGGCGTTCAGCTT & & \\
\hline \multirow[t]{2}{*}{$H M G C S 2$} & Forward & GGCGTCCCGTTTAAAGATATG & XM_010803104.3 & 64 \\
\hline & Reverse & AGTTGAAAGAGGGCAGACGTT & & \\
\hline \multirow[t]{2}{*}{$B D H$} & Forward & AGGGTCTTCGAGAAGGAAACG & NM_001034600.2 & 138 \\
\hline & Reverse & GGTTCCCAAAACAAACTGGCG & & \\
\hline \multirow[t]{2}{*}{$A C T B$} & Forward & ACGACATGGAGAAGATCTGG & NM_173979.3 & 83 \\
\hline & Reverse & ATCTGGGTCATCTTCTCACG & & \\
\hline \multirow[t]{2}{*}{$R P S 15$} & Forward & GGCGGAAGTGGAACAGAAGA & NM_001024541.2 & 97 \\
\hline & Reverse & GTAGCTGGTCGAGGTCTACG & & \\
\hline
\end{tabular}

${ }^{1}$ FGF21 = hepatic fibroblast growth factor-21; CPT1A = carnitine palmitoyltransferase $1 \mathrm{~A} ;$ PCK1 = phosphoenolpyruvate carboxykinase; $S R E B F 2=$ sterol regulatory element binding factor 2; HMGCS1 = 3-hydroxy3-methylglutaryl-coenzyme A synthase 1; $H M G C R=3$-hydroxy-3-methylglutaryl-coenzyme A reductase; $M T T P=$ microsomal triglyceride transfer protein; $A P O B 100=$ apolipoprotein $\mathrm{B} 100 ; A P O A 1=$ apolipoprotein A 1; HMGCS2 = 3-hydroxy-3-methylglutaryl-coenzyme A synthase 2; $B D H=$ BHB dehydrogenase; $A C T B$ $=\beta$-actin; $R P S 15=40 \mathrm{~S}$ ribosomal protein S15.

${ }^{2}$ From NCBI Nucleotide Database (https://www.ncbi.nlm.nih.gov/nucleotide/). 
of a normal population. Hepatic transcript abundance for all genes except SREBF2 were log-transformed before analysis to achieve a normal residual distribution, with results presented after back-transformation. Significance was declared when $P<0.05$, and tendencies were declared at $0.05 \leq P<0.10$. When treatment interactions were $P<0.05$, the slice option of SAS was used to test treatment effects at each measurement time or within parity.

\section{RESULTS AND DISCUSSION}

\section{DMI and Feeding Behavior}

Unsurprisingly, primiparous cows consumed less DM than multiparous cows both prepartum (10.3 vs. 13.0 $\pm 0.6 \mathrm{~kg} / \mathrm{d} ; P<0.01)$ and postpartum (18.4 vs. 22.9 $\pm 0.62 \mathrm{~kg} / \mathrm{d} ; P<0.001)$. Parity effects on prepartum feeding behavior included greater meal weight for multiparous cows ( 1.48 vs. $1.12 \pm 1.3 \mathrm{~kg} ; P<0.01)$ and a longer intermeal interval for multiparous cows $(0.82$ vs. $0.74 \pm 0.02 \mathrm{~h} ; P=0.04)$. Postpartum meal length was shorter $(22.7$ vs. $27.0 \pm 1.4 \mathrm{~min} ; P<0.05)$ and intermeal interval was longer for primiparous cows than for multiparous cows (1.85 vs. $1.57 \pm 0.76 \mathrm{~h} ; P=0.07$ ).

As shown in Table 3 and Figure 1A, DMI increased with the progression of lactation $(P<0.001)$; however, DMI did not differ with SCFP supplementation $(P>$ $0.69)$. In agreement, the only other 2 published studies evaluating this product (to our knowledge) did not observe an effect on DMI in transition cows (Shi et al., 2019) or mid-lactation cows (Acharya et al., 2017).

Despite no overall effects on DMI, SCFP supplementation did modulate feeding behavior both pre- and postpartum in the present study. All feeding behavior parameters except intermeal interval $(P=0.28)$ were influenced by day RTC $(P<0.01$; Table 3$)$. Supplementation with SCFP tended to increase prepartum meal count $(P=0.06$; Figure $1 \mathrm{~A})$ and decreased the time between meals $(P=0.03$; Figure $1 \mathrm{C})$, specifically during the $10 \mathrm{~d}$ preceding calving. A treatment $\times$ day RTC interaction for meal weight $(P=0.03)$ indicated that control cows consumed larger meals from $\mathrm{d}-7$ to -4 RTC. These data suggest that SCFP cows consumed lighter meals more often, with less time between meals, leading up to calving. Interestingly, a prepartum treatment $\times$ parity interaction for meal count and intermeal interval $(P \leq 0.03)$ suggested that this altered feeding behavior with SCFP mainly applied to primiparous cows. Meal count was greater (9.7 vs. $8.5 \pm 0.4 / \mathrm{d})$ and intermeal interval was lesser ( 0.65 vs. $0.82 \pm 0.04 \mathrm{~h}$ ) for primiparous SCFP than for control cows, but both were similar for multiparous SCFP and control cows (8.8 vs. $8.9 \pm 0.2 / \mathrm{d}$ and 0.82 vs. $0.81 \pm 0.02 \mathrm{~h})$. Postpartum, SCFP cows continued to consume more meals $(P=$ $0.04)$ with a tendency for less time between meals $(P=$ $0.07)$. Meal size and length did not differ by treatment $(P \geq 0.20)$.

Such modulation of feeding behavior has also been documented in previous transition cow studies supplementing either yeast culture (Yuan et al., 2015a) or active dry yeast (Bach et al., 2007; DeVries and Chevaux, 2014). The more frequent meals may contribute to improved rumen function. In yeast-supplemented late-lactation cows with increased meal frequency, rumen $\mathrm{pH}$ was also greater (Bach et al., 2007). DeVries and Chevaux (2014) debated that although yeast supplementation could modulate feeding behavior and that such alterations can stabilize rumen $\mathrm{pH}$ and fermentation, it is also possible that feeding behavior is a

Table 3. Feed intake, water intake, and feeding behavior parameters for control cows and cows supplemented with a Saccharomyces cerevisiae fermentation product (SCFP) from $-29 \pm 5$ d relative to calving through 42 DIM

\begin{tabular}{|c|c|c|c|c|c|c|c|c|}
\hline Item & \multicolumn{2}{|c|}{ Treatment (Trt) } & $\begin{array}{c}\text { Pooled } \\
\text { SEM }\end{array}$ & \multicolumn{5}{|c|}{$P$-value } \\
\hline $\mathrm{DMI}, \mathrm{kg} / \mathrm{d}$ & 11.52 & 11.72 & 0.50 & 0.70 & $<0.001$ & 0.76 & $<0.01$ & $>0.20$ \\
\hline Meal count, no./d & 8.66 & 9.27 & 0.22 & 0.06 & $<0.001$ & 0.44 & 0.52 & 0.03 \\
\hline Meal weight, kg & 1.31 & 1.29 & 0.06 & 0.75 & $<0.001$ & 0.03 & $<0.01$ & $>0.20$ \\
\hline Meal length, min & 28.28 & 29.49 & 0.94 & 0.28 & $<0.001$ & 0.03 & 0.91 & $>0.20$ \\
\hline Water intake, L/d & 104.3 & 109.7 & 3.7 & 0.16 & $<0.001$ & 0.60 & $<0.001$ & $>0.20$ \\
\hline DMI, $\mathrm{kg} / \mathrm{d}$ & 20.58 & 20.69 & 0.52 & 0.84 & $<0.001$ & 0.75 & $<0.001$ & $>0.20$ \\
\hline Meal count, no./d & 11.32 & 12.60 & 0.45 & 0.04 & $<0.001$ & 0.66 & 0.45 & $>0.20$ \\
\hline Meal weight, $\mathrm{kg}$ & 2.00 & 1.91 & 0.12 & 0.59 & $<0.001$ & 0.34 & 0.28 & $>0.20$ \\
\hline Meal length, min & 23.81 & 25.90 & 1.30 & 0.20 & $<0.001$ & 0.81 & $<0.05$ & $>0.20$ \\
\hline Intermeal interval, h & 1.81 & 1.62 & 0.09 & 0.07 & $<0.001$ & 0.55 & 0.07 & $>0.20$ \\
\hline
\end{tabular}

\footnotetext{
${ }^{1}$ Time is by week for DMI and by day relative to calving for feeding behavior parameters.
} 

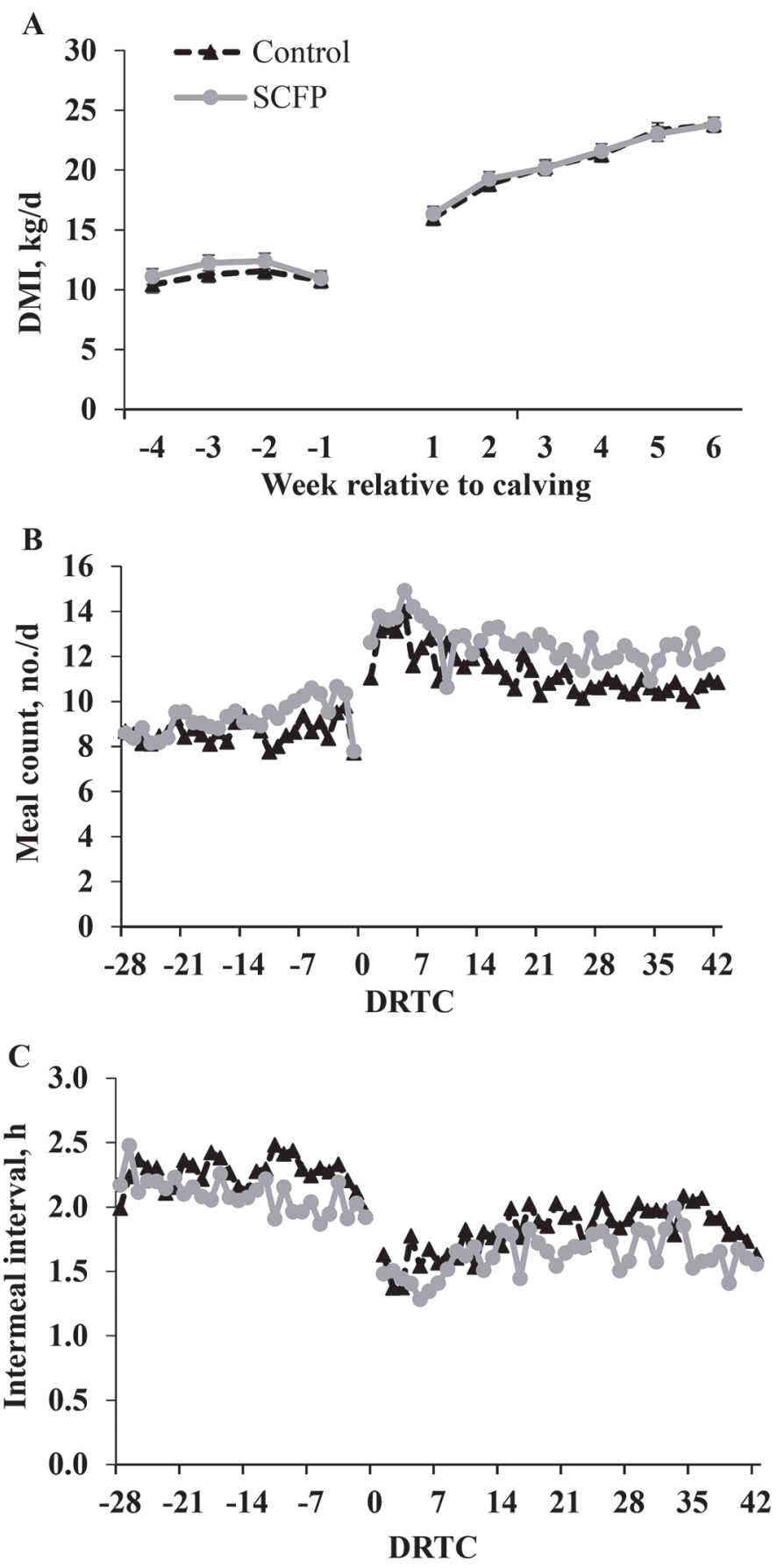

Figure 1. Dry matter intake (A), meal count (B), and intermeal interval (C) for control cows and cows supplemented with Saccharomyces cerevisiae fermentation product (SCFP) from $-29 \pm 5 \mathrm{~d}$ relative to calving (DRTC) through 42 DIM. An effect of time was present both prepartum and postpartum for all measures $(P<0.001)$. (A) Dry matter intake did not differ by treatment $(P \geq 0.75)$. (B) The SCFP cows tended to consume more meals per day prepartum $(P=0.06)$ and increased meals per day postpartum $(P=0.03)$. Prepartum SEM $=0.22$, postpartum SEM $=0.45$. (C) Supplementation with SCFP decreased time between meals prepartum $(P=0.03)$ and tended to decrease intermeal interval postpartum $(P=0.07)$. Prepartum SEM $=$ 0.05 , postpartum $\mathrm{SEM}=0.09$. secondary effect in these circumstances. In such case, yeast supplementation may result in more consistent VFA production and improved fiber digestibility and therefore a more rapid return to eating. Through either mechanism, stabilization of rumen pH by SCFP (Shen et al., 2018) would support its supplementation during the transition period when cows are at high risk for experiencing low rumen pH (Penner et al., 2014).

\section{BW, Body Condition, Milk Production, and Energy Balance}

Cows experienced the typical decrease in BCS and BW during the transition to lactation $(P<0.001)$; however, there was no effect of treatment or treatment $\times$ time for either $(P>0.50)$. On average, from the time of enrollment through 42 DIM cows lost 0.7 BCS units (from 3.6 to 2.9), and from calving through 42 DIM BW decreased by $46 \mathrm{~kg}$ (from 646 to $600 \mathrm{~kg}$ ). As shown in Table 4 and Figure 2A, milk production expressed as milk, ECM, or FCM yield was unaffected by treatment $(P \geq 0.32)$. Several studies have failed to observe effects of SCFP on milk yield (Dann et al., 2000; Yuan et al., 2015a), whereas others have reported positive effects (Ramsing et al., 2009; Zaworski et al., 2014; Acharya et al., 2017; Dias et al., 2018a). The variation in production responses has been attributed to differences in DIM (Poppy et al., 2012), dietary NDF concentration (Robinson and Erasmus, 2009), and product evaluated (Yuan et al., 2015a). Studies also differ in power to detect treatment effects on milk yield. Milk fat concentration increased $(P=0.01)$ and milk fat yield tended to increase $(P=0.10$; Figure $2 \mathrm{~B})$ for SCFP cows, with significant differences in wk 4 and 5 (Figure 2B). We observed no differences for milk protein yield and content, lactose yield, or milk somatic cell linear score $(P>0.15)$. Milk lactose concentration tended to be greater for the control $(P=0.06)$, and MUN concentration tended to be greater for $\operatorname{SCFP}(P=0.06)$. Although the net economic impacts depend on market conditions, one partial budget analysis that accounted for milk income and costs of feed, SCFP, and ketosis treatment suggested that responses to SCFP supplementation in this study generated a positive financial return (Olagaray et al., 2019).

Greater milk fat content in early lactation can indicate greater fat mobilization; however, lack of effects on BCS and timing of the milk fat response (wk 4 and 5) make that unlikely. Cows are at greater risk for ruminal acidosis after parturition (Penner et al., 2007). Supplementation with SCFP has been shown to attenuate the associated decrease in milk fat content (Li et al., 2016); however, the timing of our observed response does not appear to align with this mechanism. Recent analysis 
of a feeding behavior database revealed that milk fat yield was associated with meal frequency $(+0.02 \mathrm{~kg} /$ meal; Johnston and DeVries, 2018). As discussed previously, cows with greater meal frequency in response to SCFP supplementation also exhibited increased rumen pH (Bach et al., 2007). Even without changes in feeding behavior, SCFP increased rumen $\mathrm{pH}$ and reduced ruminal lactate concentrations (Dias et al., 2018b). Saccharomyces cerevisiae fermentation product is believed to contain growth factors that stimulate ruminal microbial growth, especially for lactate utilizers (Callaway and Martin, 1997; Chaucheyras-Durand et al., 2008). Therefore, through its effects on microbial populations, SCFP can increase rumen $\mathrm{pH}$. Greater rumen $\mathrm{pH}$ prevents shifts in the rumen biohydrogenation pathways (Bauman and Griinari, 2001), decreasing risk of milk fat depression. Fiber-digesting bacteria that largely produce acetate are also more productive and prolific at greater rumen $\mathrm{pH}$. Wiedmeier et al. (1987) observed an increase in cellulolytic bacterial populations with SCFP, which could lead to increased acetate supply. Acetate is one of the main lipogenic precursors for de novo fatty acid synthesis, and increasing its supply via enhanced cellulolytic bacteria productivity could be partially responsible for our observed increased milk fat content. The recent experiment by Urrutia et al. (2017) supports this hypothesis as increased ruminal acetate supply via ruminal infusion increased milk fat concentration through increased C16 and de novo fatty acid yields. Although rumen function influences milk fat, the time effect makes explanations for this effect puzzling.
Energy balance calculated assuming equal digestibility differed by parity $(P<0.01)$, week $(P<0.001)$, and treatment $(P=0.03)$. A parity $\times$ week interaction $(P$ $<0.001$ ) indicated tendencies for greater energy balance during wk -4 and -3 RTC but significantly lesser energy balance during wk 1 to 5 RTC for multiparous compared with primiparous cows. Overall, energy balance was less in multiparous compared with primiparous cows $(-7.02$ vs. $-3.47 \pm 0.83 \mathrm{Mcal} / \mathrm{d}, P<0.01)$. Energy balance was less for SCFP cows ( -6.15 vs. -4.34 $\pm 0.74 \mathrm{Mcal} / \mathrm{d}$ ), but despite this, body condition loss did not differ between treatments. This incongruence between calculated energy balance and BCS change could indicate greater diet digestibility or metabolizability with SCFP or both. It is known that SCFP can affect diet digestibility (Allen and Ying, 2012; Dias et al., 2018a), providing a plausible mechanism by which NE harvest could be improved.

\section{Metabolic Signaling}

Temporal patterns for plasma FFA, BHB, insulin, and glucose reflected the typical metabolic and endocrine changes during the transition period $(P<0.001)$. The metabolic profile was not altered by SCFP supplementation $(P>0.35$; Figure 3$)$. Several cows were treated for SCK around the time of blood sampling, and therefore their BHB results could be biased by the administration of glucogenic precursors. Thus, cows treated within $1 \mathrm{~d}$ of sampling were excluded from the BHB analysis presented in Figure 3B. The analysis was also performed with all cows included. Similar to previ-

Table 4. Lactation performance and energy balance for control cows and cows supplemented with a Saccharomyces cerevisiae fermentation product (SCFP) from $29 \pm 5$ d prepartum to 42 DIM

\begin{tabular}{|c|c|c|c|c|c|c|}
\hline Item & \multicolumn{2}{|c|}{ Treatment (Trt) } & $\begin{array}{c}\text { Pooled } \\
\text { SEM }\end{array}$ & \multicolumn{3}{|c|}{$P$-value ${ }^{1}$} \\
\hline Milk, kg/d & 41.35 & 40.23 & 1.26 & 0.43 & $<0.001$ & 0.24 \\
\hline Milk fat, $\mathrm{kg} / \mathrm{d}$ & 1.64 & 1.77 & 0.08 & 0.10 & $<0.001$ & 0.09 \\
\hline Milk protein, \% & 3.03 & 3.12 & 0.04 & 0.16 & $<0.001$ & $<0.01$ \\
\hline Milk protein, $\mathrm{kg} / \mathrm{d}$ & 1.24 & 1.21 & 0.04 & 0.48 & $<0.001$ & 0.61 \\
\hline MUN, mg/dL & 11.51 & 12.42 & 0.38 & 0.06 & $<0.001$ & 0.21 \\
\hline Milk somatic cell linear score ${ }^{2}$ & 2.32 & 1.94 & 0.28 & 0.29 & $<0.001$ & 0.55 \\
\hline $\mathrm{ECM}, \mathrm{kg} / \mathrm{d}$ & 43.89 & 45.21 & 1.66 & 0.41 & $<0.001$ & 0.09 \\
\hline $\mathrm{FCM}, \mathrm{kg} / \mathrm{d}$ & 43.90 & 45.93 & 1.90 & 0.32 & $<0.001$ & 0.20 \\
\hline BW change, ${ }^{3} \mathrm{~kg}$ & -41.2 & -44.5 & 7.9 & 0.74 & - & - \\
\hline BCS change ${ }^{4}$ & -0.61 & -0.73 & 0.07 & 0.22 & - & - \\
\hline Energy balance, Mcal/d & -4.34 & -6.15 & 0.74 & 0.03 & $<0.001$ & 0.20 \\
\hline
\end{tabular}

${ }^{1}$ Parity was significant for all parameters except milk protein concentration $(P=0.10)$ and MUN $(P=0.86)$, and none had a parity $\times$ treatment interaction (all $P>0.14$ ).

${ }^{2}$ Somatic cell linear score $=\log _{2}(\mathrm{SCC} / 100)+3$.

${ }^{3}$ Body weight change from calving through 42 DIM.

${ }^{4}$ Body condition score change from enrollment $(\mathrm{d}-29 \pm 5)$ to 42 DIM. 
ous results, there was no effect of treatment $(P=0.57)$ or treatment $\times$ week interaction $(P=0.12)$. Minimal alterations to metabolism have been reported by other studies investigating yeast culture supplementation in transition cows (Ramsing et al., 2009; Zaworski et al., 2014; Yuan et al., 2015a). Most notable was that yeast supplementation increased plasma BHB with a quadratic dose effect in Yuan et al. (2015a). Potential explanations provided by authors included increased ruminal butyrate production or increased hepatic ketogenesis. The latter was consistent with a tendency for increased plasma FFA concentration and decreased (quadratic dose effect) plasma glucose.
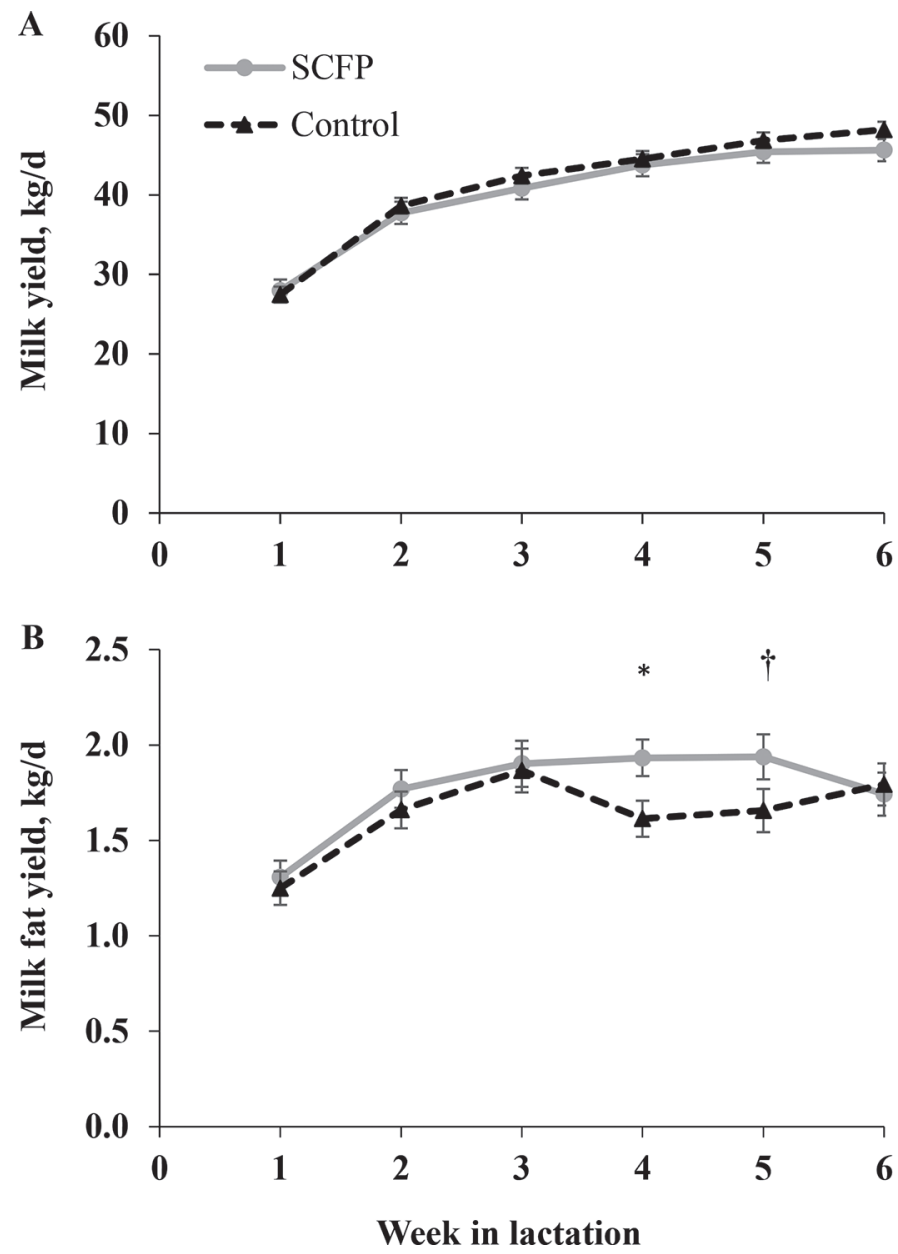

Figure 2. (A) Milk yield was not different between control cows and cows supplemented with Saccharomyces cerevisiae fermentation product (SCFP) from $\mathrm{d}-29 \pm 5$ relative to calving through 42 DIM $(P=0.43)$. There was an effect of week $(P<0.001)$ but no treatment $\times$ week interaction $(P=0.24)$. (B) Weekly milk fat yield was not different for cows supplemented with SCFP compared with control cows $(P=0.10)$. Milk fat yield differed by week $(P<0.001)$, and there was a tendency for a treatment $\times$ week interaction $(P=0.09)$. Treatment differences are indicated by $*(P<0.05)$ and $\dagger(0.05 \leq P<0.10)$. Values are least squares means; error bars represent standard errors.

\section{Hepatic Metabolism}

Liver TG increased from prepartum to postpartum, but there was no effect of $\operatorname{SCFP}(P>0.40$; Figure $4 \mathrm{~A})$. Liver TG was greater in multiparous cows than in primiparous cows (1.14 vs. $1.01 \pm 0.01 \%$ of wet weight; $P=0.01)$. Typically, lipid mobilization is greater in multiparous cows; thus, it is logical that we observed greater liver TG in multiparous cows.

Our findings of increased FGF21 relative mRNA abundance from prepartum to postpartum $(P<0.001)$, the time when energy balance was negative, correspond with upregulation during fasting (Fisher and MaratosFlier, 2016). Interestingly, relative abundance of FGF21 was greater for primiparous cows than for multiparous cows (1.00 vs. $0.34 \pm 0.59 ; P=0.03)$. Relative mRNA abundance of $P C K 1$ tended to be greater for SCFP $(P$ $=0.08)$. Transcript abundance for the mitochondrial fatty acid transport enzyme CPT1A did not differ by treatment $(P=0.19)$ or week $(P=0.54)$ but was greater in multiparous cows (3.10 vs. $1.00 \pm 1.39 ; P=0.04)$. To our knowledge, this is the first study to investigate the effects of SCFP on these particular transcripts involved in lipid and glucose metabolism. Further investigation is required to explain the tendency for increased $P C K 1$ abundance that occurred in SCFP cows.

\section{Cholesterol Metabolism}

Interestingly, liver total cholesterol concentration decreased from wk -3 to 2 RTC $(P<0.001)$, and wk 2 liver TG and cholesterol concentrations were negatively correlated $\left(\mathrm{R}^{2}=0.18 ; P<0.01\right)$. These results are contrary to the pattern reported previously in which hepatic total cholesterol content increased from wk -3 to wk 1 with subsequent decreases (Schlegel et al., 2012). Similarly, Bobe et al. (2003) reported peak hepatic free cholesterol at 12 DIM, at which point it decreased to prepartum levels by wk 5 . The different forms of liver cholesterol analyzed between our study and Bobe et al. (2003) could account for liver cholesterol concentrations increasing after parturition in Bobe et al. (2003) but decreasing in our study; however, Schlegel et al. (2012) also analyzed total cholesterol and reported time effects similar to those in Bobe et al. (2003). Liver cholesterol concentration tended to be lesser in SCFP than in the control $(P<0.10$; Figure 4B). To our knowledge, this is the first study to investigate the effects of SCFP on hepatic cholesterol content. Decreased hepatic cholesterol content could be the result of increased very low-density lipoprotein formation and lipid export; however, SCFP did not decrease liver TG content. Additional potential explanations for decreased cholesterol content include 
less cholesterol synthesis, less uptake into the liver, and increased transformation to bile acids (Schlegel et al., 2012).

Effects of SCFP on cholesterol metabolism also included increased plasma cholesterol concentration throughout the study period $(P=0.02)$. Other studies evaluating effects of yeast products on plasma cholesterol reported no treatment differences (Piva et al., 1993; Yalcin et al., 2011); however, mid-lactation cows were used. Cholesterol metabolism is affected by nutrient and energy deficiency and therefore differs with stage of lactation (Gross et al., 2015). The change in plasma cholesterol, decreasing as parturition approached, with a nadir at wk 1 and a subsequent increase through wk 5 $(P<0.001)$, was similar to previously reported patterns (Bernabucci et al., 2004; Schlegel et al., 2012; Kessler et al., 2014). Decreased plasma cholesterol concentrations within the first week of lactation could be the result of less liver synthesis of cholesterol, decreased very lowdensity lipoprotein secretion from the liver, increased cholesterol uptake by the mammary gland (Kessler et al., 2014) and other tissues (Schlegel et al., 2012), and less reverse cholesterol transport (Kessler et al., 2014).

It has been suggested that plasma cholesterol concentration is mainly influenced by hepatic cholesterol synthesis (van Dorland et al., 2009). We investigated several gene transcripts involved in cholesterol metabolism, including those involved in biosynthesis (SREBP2, HMGCR, HMGCS1), transport (APOA1, $A P O B 100)$, and construction of lipoproteins (MTTP). The only transcript investigated that differed with time was APOA1, which increased from wk -3 to wk $2(P$ $<0.001$ ). Nascent high-density lipoprotein particles are formed by lipidation of APOA1 in the liver (Vaughan and Oram, 2006). Therefore, greater mRNA abundance postpartum when liver cholesterol content was lesser could suggest increased production of reverse cholesterol transport machinery and components. Previous studies have reported increased mRNA abundance of genes involved in cholesterol synthesis at the onset of lactation
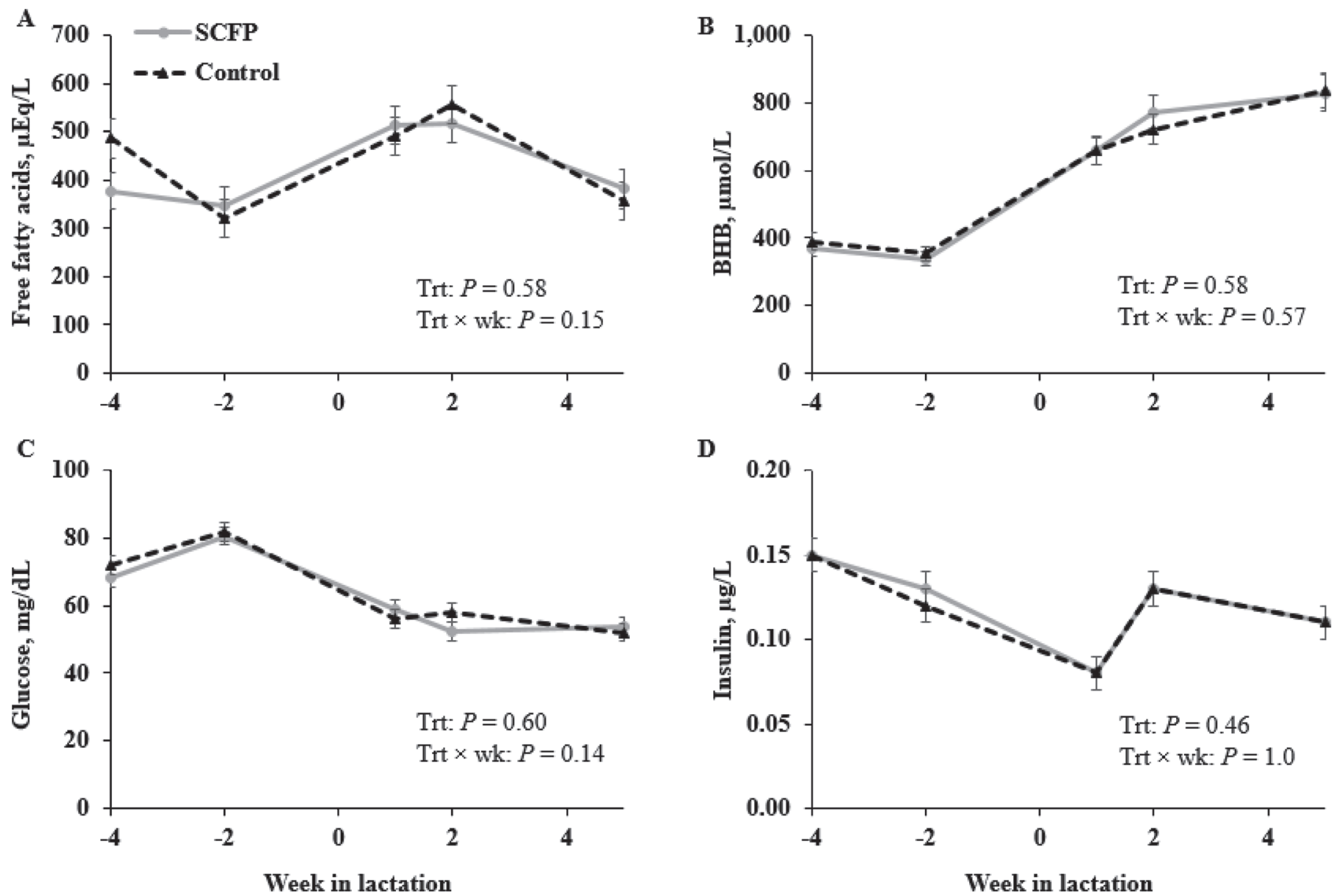

Figure 3. Plasma concentrations of free fatty acids (A), BHB (B), glucose (C), and insulin (D) in cows supplemented with Saccharomyces cerevisiae fermentation product (SCFP) from d $-29 \pm 5$ relative to calving through 42 DIM. Values are least squares means; error bars represent standard errors. Trt $=$ treatment. 
A

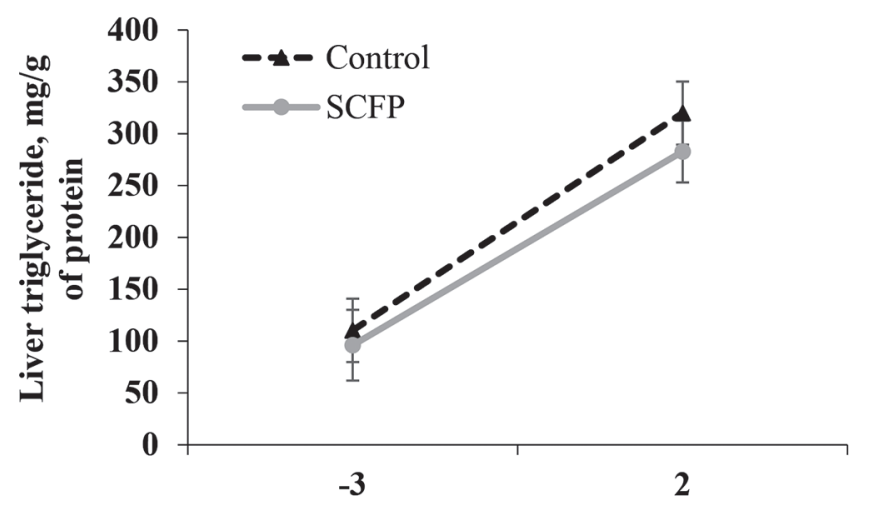

B

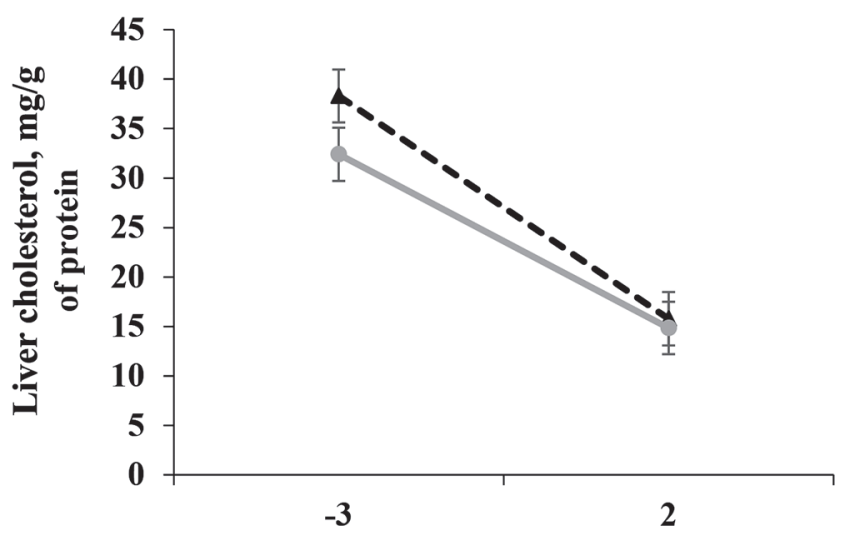

C

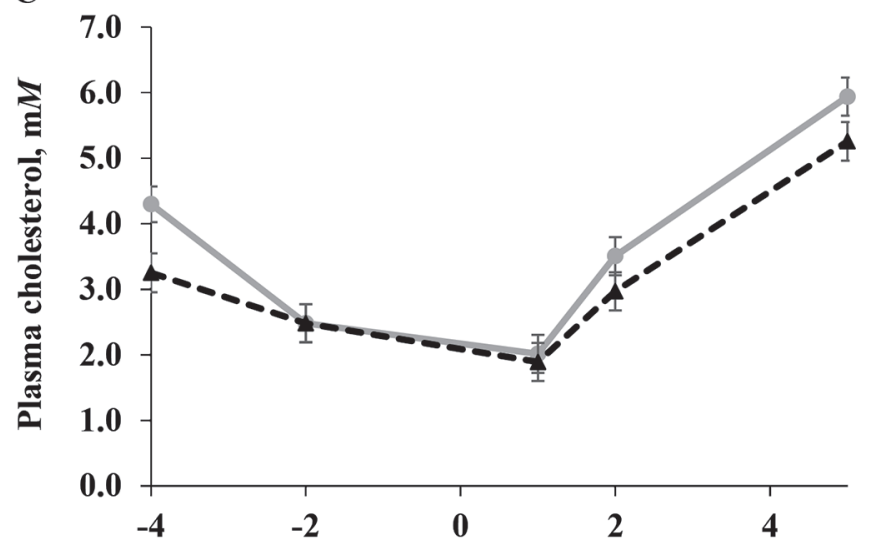

Week in lactation

Figure 4. Liver triglyceride (A), liver cholesterol (B), and plasma cholesterol (C) content in cows supplemented with Saccharomyces cerevisiae fermentation product (SCFP) from d $-29 \pm 5$ relative to calving through 42 DIM. (A) Liver triglyceride concentration did not differ by treatment $(P>0.41)$. There was an effect of week $(P<$ $0.001)$ but no treatment $\times$ week interaction $(P=0.67)$. (B) Liver cholesterol content tended to be less in SCFP cows compared with control cows $(P<0.10)$. There was an effect of week $(P<0.001)$ but no effect of treatment $\times$ week $(P>0.30)$. (C) Plasma cholesterol was greater for SCFP $(P=0.02)$ and differed by week $(P<0.001)$, but there was no treatment $\times$ week interaction $(P=0.20)$. Values are least squares means; error bars represent standard errors.
(Schlegel et al., 2012; Weber et al., 2013; Kessler et al., 2014), making it surprising that we did not observe any effects of time. It is possible our d 14 sample was too late to capture the expected postpartum increase in these transcripts. Relative mRNA abundance was not altered by SCFP supplementation for any of the genes $(P>0.10$; Table 5).

Further investigation is required to understand the associations between plasma and hepatic levels of cholesterol with dairy cow health and productivity. Overinterpretation is a risk when examining changes in gene expression to provide explanation for systemic changes. Schlegel et al. (2012) observed no association between expression of hepatic enzymes of cholesterol synthesis and plasma cholesterol concentration; expression of $H M G C R$ and HMGCS1 was greatest at wk 1 when plasma cholesterol concentration was least (Schlegel et al., 2012).

\section{Health Outcomes}

Incidence of common periparturient diseases occurring throughout the study period is provided in Table 6. No metabolic diseases recorded, except for SCK, differed by treatment $(P>0.10)$. Incidence of SCK was greater in cows supplemented with SCFP compared with control cows $(38 \%$ vs. $12 \%, P=0.02$, Fisher's exact test), and days of glucogenic treatment were greater (1.7 vs. $0.4 \pm 0.3 \mathrm{~d} ; P=0.01)$. Additional analyses were conducted to understand the observed increase in SCK incidence despite little evidence of an overall treatment effect on ketone concentrations in plasma or decreased energy balance during the window of time when ketosis was observed. The majority of ketosis diagnosis occurred between 10 and 20 DIM ( $\mathrm{n}=8$; SCFP $=6$, control $=2$ ). Because of the timing, wk 2 data from all cows were used to try to understand potential mechanisms underlying this effect. Appropriate diagnosis of SCK by urine acetoacetic acid concentrations is supported by greater wk 2 plasma BHB concentrations in cows diagnosed with SCK compared with those that were not $(2,068.3 \pm 135.0$ vs. $792.5 \pm 62.3 \mu M ; P<$ 0.001). Analysis of wk 2 BHB concentrations independently demonstrated a parity $\times$ treatment interaction $(P=0.02$; Figure 5$)$. Treatment did not affect wk 2 plasma BHB in primiparous cows, but SCFP increased $\mathrm{BHB}$ concentrations in multiparous cows.

To further investigate the SCK effect, we analyzed hepatic mRNA abundance for 2 enzymes in the ketogenic pathway: HMGCS2, which facilitates the rate-limiting formation of hydroxy-3-methylglutaryl-coenzyme A, and $B D H$, which reduces acetoacetate to produce BHB (Hegardt, 1999). Aligning with incidence of SCK, 
SACCHAROMYCES CEREVISIAE FERMENTATION PRODUCT AND TRANSITION COWS

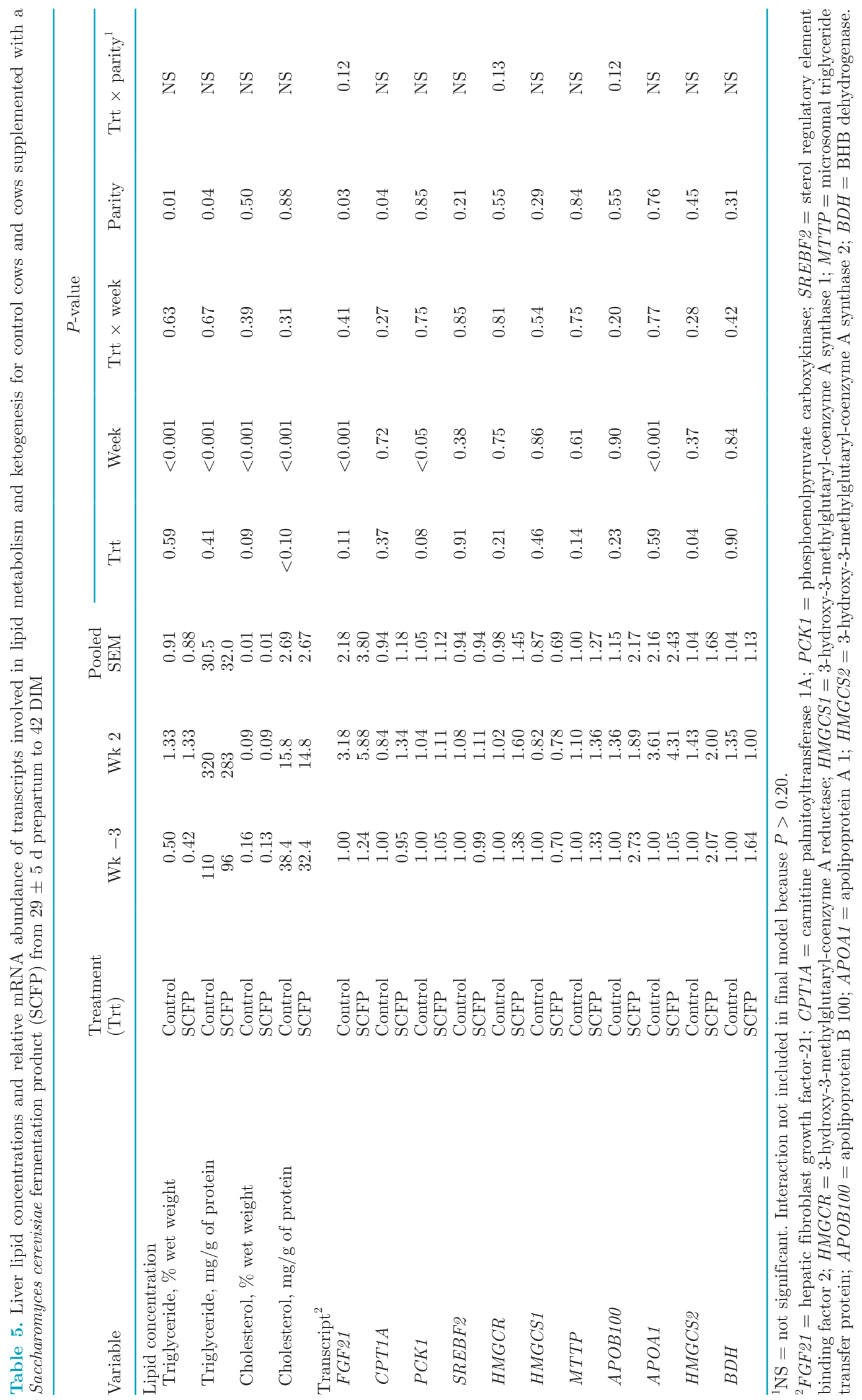




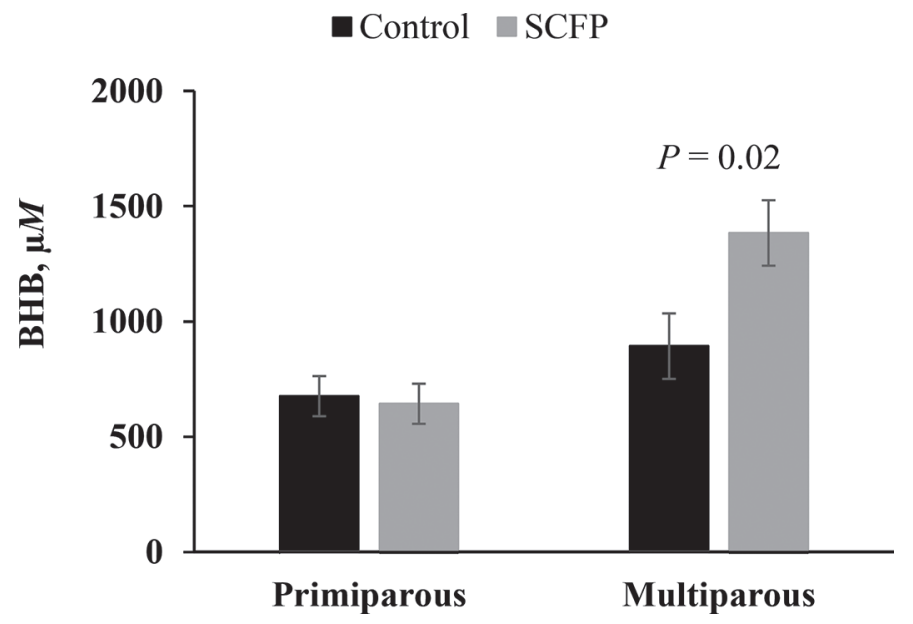

Figure 5. Analyzed independently, wk 2 BHB concentrations demonstrated a significant parity $\times$ treatment interaction. Although supplementation with a Saccharomyces cerevisiae fermentation product (SCFP) from d $-29 \pm 5$ relative to calving through 42 DIM did not affect BHB in primiparous cows, SCFP increased BHB in multiparous cows. Values are least squares means; error bars represent standard errors.

HMGCS2 was greater for SCFP cows compared with control cows $(P=0.03)$. Despite this alignment of treatment effects, HMGCS2 did not differ by parity or time RTC $(P>0.35)$. Relative $B D H$ abundance did not differ by treatment, time, or parity $(P>0.30)$. Previous studies have shown increased relative $B D H$ abundance in response to nutrition-induced ketosis (Loor et al., 2007); however, abundance of HMGCS2 and BDH has not always coincided with increased plasma BHB concentrations (van Dorland et al., 2009, 2014; Graber et al., 2010). In a study that examined cows with different metabolic loads (defined by plasma BHB, FFA, and glucose concentrations), BDH2 and HMGCS2 did not differ between the 2 groups even though plasma BHB

Table 6. Disease incidence through 42 DIM for control cows and cows supplemented with a Saccharomyces cerevisiae fermentation product (SCFP) from $29 \pm 5$ d prepartum to 42 DIM

\begin{tabular}{lcc}
\hline Item & Control & SCFP \\
\hline At-risk & & \\
Fever & 30 & 34 \\
Displaced abomasum & 9 & 5 \\
Retained placenta & 0 & 2 \\
Ketosis & 2 & 0 \\
Mastitis & 4 & $12^{*}$ \\
Other $^{2}$ & 2 & 1 \\
\hline
\end{tabular}

\footnotetext{
${ }^{1}$ Includes all cows that surpassed the exclusion criteria at calving. Cows excluded from analysis due to periparturient issues were included.

${ }^{2}$ Includes 1 case of peritonitis resulting in death (control), 3 foot injuries (2 control, $1 \mathrm{SCFP}$ ), and 1 diarrhea/digestive upset at calving (control).

*Fisher's exact test: $P=0.02$. No other conditions were significantly affected by treatment.
}

did (van Dorland et al., 2014). It is possible that small changes at the mRNA level, although not statistically significant for $B D H$, were sufficient to generate phenotypic changes (Graber et al., 2010). It is also possible that BHB synthesis is more heavily regulated by posttranslational mechanisms (Quant et al., 1990).

It is possible that the greater incidence of ketosis with SCFP contributed to our observed differences in cholesterol metabolism. Both SREBF2 and HMGCS1 (cholesterol biosynthesis) were downregulated in cows during nutrition-induced ketosis (Loor et al., 2007). Because cholesterol synthesis and ketogenesis share a common pathway utilizing the enzyme $H M G C S$, it is unsurprising that the metabolism of the 2 may be related. Although SCFP did not alter SREBF2 and $H M G C S 1$ mRNA abundance in this study, it is interesting that the tendency for less liver cholesterol and increased plasma cholesterol coincided with greater SCK.

Occurrence of ketosis is typically concerning because it is associated with depressed feed intake and decreased performance (Duffield et al., 2009; Ospina et al., 2010); however, recent BHB infusion data suggest that elevated BHB in early lactation may not necessarily be problematic. Infusion of BHB for $48 \mathrm{~h}$ at rates that elevated plasma BHB to levels of SCK (1.5 to $2.0 \mathrm{mmol} / \mathrm{L}$ ) decreased plasma glucose concentrations but had no effect on DMI, milk yield, or ECM (Zarrin et al., 2013). Despite epidemiological evidence linking decreased cow performance with SCK (Ospina et al., 2010), more recent studies have reported increased milk yield and fat concentration (Rathbun et al., 2017) and greater first test-day milk (Vanholder et al., 2015) in cows diagnosed with SCK during the first 2 wk of lactation. These observational studies point to greater earlylactation milk yield for SCK cows, although associations with peak milk yield are more variable. This disconnect between epidemiological studies and responses to infused BHB may exist because most cases of SCK in transition cows are secondary to other events (e.g., mastitis or retained placenta) that may account for the negative effects on health and productivity (Ospina et al., 2010; Zarrin et al., 2013). Thus, the elevated BHB observed in cows diagnosed with SCK in the current study might not be detrimental to cow productivity.

Increased SCK could also be the result of shifts in rumen fermentation that resulted in greater plasma BHB. Greater supply of ruminal acetate increased plasma BHB (Urrutia and Harvatine, 2017), largely due to microbial conversion of acetate to butyrate and metabolism of butyrate to BHB in the rumen epithelium (Sutton et al., 2003). As previously discussed, SCFP can modulate rumen fermentation toward increased acetate production. Ruminally infused butyrate also increased plasma BHB concentration that was ac- 
companied by a decrease in plasma glucose (Herrick et al., 2018). Although not measured in our study, it is possible that SCFP caused shifts in ruminal fermentation that partially contributed to increased systemic concentrations of $\mathrm{BHB}$ and thus increased incidence of SCK. Because only the greatest doses of ruminal acetate $(15 \mathrm{~mol} / \mathrm{d}$; Urrutia and Harvatine, 2017) and butyrate $(2 \mathrm{~g} / \mathrm{kg}$ of BW; Herrick et al., 2018) infusion increased plasma BHB concentrations to levels near the $1.2 \mathrm{~m} M$ cut-point for SCK (1.175 and $1.45 \mathrm{~m} M$, respectively), it is likely that any shifts in ruminal fermentation by SCFP would have only partially contributed to the increased ketone concentrations used to diagnose SCK. Likewise, if altered ruminal fermentation is a key underlying mechanism for responses to SCFP, it is difficult to explain why the timing of SCK and milk fat yield responses differed. Several possible explanations for increased incidence of subclinical ketosis with SCFP have been presented, but the exact mechanisms remain unknown.

\section{CONCLUSIONS}

Supplementation with SCFP during the transition period altered prepartum and postpartum feeding behavior, with increased meals per day and decreased time between those meals. Although no effects were detected for DMI, milk yield, milk protein, or somatic cell linear score, milk fat content was increased by approximately $13 \%$ in cows receiving SCFP, with differences beginning after the time period that lipid mobilization is greatest during the transition period. Body weight, BCS, and energy metabolites were unaffected by treatment. Liver metabolic signals were mostly unaffected by treatment, but there was a tendency for SCFP to increase PCK1 mRNA abundance. Supplementation with SCFP led to shifts in cholesterol metabolism, tending to decrease hepatic cholesterol and increase plasma cholesterol. Treatment also increased incidence of SCK and increased the rate-limiting ketogenic enzyme HMGCS2 but did not affect $B D H$, encoding the final enzyme in the ketogenesis pathway. Overall, SCFP supplementation during the transition period increased number of meals per day with less time between meals, increased milk fat concentration, altered cholesterol metabolism, and increased incidence of SCK, but early-lactation milk yield and metabolism were otherwise unaffected.

\section{ACKNOWLEDGMENTS}

This work is contribution no. 19-113-J from the Kansas Agricultural Experiment Station (Manhattan, KS). This work was supported by USDA National Institute of Food and Agriculture (Washington, DC) Hatch project
1018048. The authors thank Diamond V (Cedar Rapids, IA) for financial support of this research. For assistance in animal care and feeding and laboratory work, the authors thank Mike Scheffel (Manhattan, KS), the staff at the Kansas State University Dairy Cattle Teaching and Research Center, and undergraduate and graduate students Matthew Anguiano, Jeremiah Clark, Danielle Hausler, Joseph McIntosh, Chadron Koehn, Dariyan Springfield, Melissa Riley, Caroline Ylioja, and James Shaffer (Manhattan, KS).

\section{REFERENCES}

Acharya, S., J. P. Pretz, I. Yoon, M. F. Scott, and D. P. Casper. 2017. Effects of Saccharomyces cerevisiae fermentation products on the lactational performance of mid-lactation dairy cows. Transl. Anim. Sci. 1:221-228. https://doi.org/10.2527/tas2017.0028.

Allen, M. S., and Y. Ying. 2012. Effects of Saccharomyces cerevisiae fermentation product on ruminal starch digestion are dependent upon dry matter intake for lactating cows. J. Dairy Sci. 95:65916605. https://doi.org/10.3168/jds.2012-5377.

AOAC International. 2012. Official Methods of Analysis. 19th ed. Association of Official Analytical Chemists, Gaithersburg, MD.

Bach, A., C. Iglesias, and M. Devant. 2007. Daily rumen pH pattern of loose-housed dairy cattle as affected by feeding pattern and live yeast supplementation. Anim. Feed Sci. Technol. 136:146-153. https://doi.org/10.1016/j.anifeedsci.2006.09.011.

Bauman, D. E., and J. M. Griinari. 2001. Regulation and nutritional manipulation of milk fat: Low-fat milk syndrome. Livest. Prod. Sci. 70:15-29.

Bernabucci, U., B. Ronchi, L. Basiricò, D. Pirazzi, F. Rueca, N. Lacetera, and A. Nardone. 2004. Abundance of mRNA of apolipoprotein B100, apolipoprotein E, and microsomal triglyceride transfer protein in liver from periparturient dairy cows. J. Dairy Sci. 87:2881-2888. https://doi.org/10.3168/jds.S0022-0302(04)73418 $-9$.

Bobe, G., B. N. Ametaj, J. W. Young, and D. C. Beitz. 2003. Effects of exogenous glucagon on lipids in lipoproteins and liver of lactating dairy cows. J. Dairy Sci. 86:2895-2903. https://doi.org/10.3168/ jds.S0022-0302(03)73886-7.

Callaway, E. S., and S. A. Martin. 1997. Effects of a Saccharomyces cerevisiae culture on ruminal bacteria that utilize lactate and digest cellulose. J. Dairy Sci. 80:2035-2044. https://doi.org/10 .3168/jds.S0022-0302(97)76148-4.

Chaucheyras-Durand, F., N. D. Walker, and A. Bach. 2008. Effects of active dry yeasts on the rumen microbial ecosystem: Past, present and future. Anim. Feed Sci. Technol. 145:5-26. https://doi.org/10 .1016/j.anifeedsci.2007.04.019.

Dann, H. M., J. K. Drackley, G. C. Mccoy, M. F. Hutjens, and J. E. Garrett. 2000. Effects of yeast culture (Saccharomyces cerevisiae) on prepartum intake and postpartum intake and milk production of Jersey cows. J. Dairy Sci. 83:123-127. https://doi.org/10.3168/ jds.S0022-0302(00)74863-6.

DeVries, T. J., and E. Chevaux. 2014. Modification of the feeding behavior of dairy cows through live yeast supplementation. J. Dairy Sci. 97. https://doi.org/10.3168/jds.2014-8226.

Dias, A. L. G., J. A. Freitas, B. Micai, R. A. Azevedo, L. F. Greco, and J. E. P. Santos. 2018a. Effect of supplemental yeast culture and dietary starch content on rumen fermentation and digestion in dairy cows. J. Dairy Sci. 101:201-221. https://doi.org/10.3168/ jds.2017-13241.

Dias, A. L. G., J. A. Freitas, B. Micai, R. A. Azevedo, L. F. Greco, and J. E. P. Santos. 2018b. Effects of supplementing yeast culture to diets differing in starch content on performance and feeding behavior of dairy cows. J. Dairy Sci. 101:186-200. https://doi.org/ 10.3168/jds.2017-13240. 
Duffield, T. F., K. D. Lissemore, B. W. McBride, and K. E. Leslie. 2009. Impact of hyperketonemia in early lactation dairy cows on health and production. J. Dairy Sci. 92:571-580. https://doi.org/ 10.3168/jds.2008-1507.

Etheridge, R. D., G. M. Pesti, and E. H. Foster. 1998. A comparison of nitrogen values obtained utilizing the Kjeldahl nitrogen and Dumas combustion methodologies (Leco CNS 2000) on samples typical of an animal nutrition analytical laboratory. Anim. Feed Sci. Technol. 73:21-28.

Fisher, F. M., and E. Maratos-Flier. 2016. Understanding the physiology of FGF21. Annu. Rev. Physiol. 78:223-241. https://doi.org/10 .1146/annurev-physiol-021115-105339.

Graber, M., S. Kohler, T. Kaufmann, M. G. Doherr, R. M. Bruckmaier, and H. A. van Dorland. 2010. A field study on characteristics and diversity of gene expression in the liver of dairy cows during the transition period. J. Dairy Sci. 93:5200-5215. https://doi.org/ 10.3168/jds.2010-3265.

Gross, J. J., E. C. Kessler, C. Albrecht, and R. M. Bruckmaier. 2015 Response of the cholesterol metabolism to a negative energy balance in dairy cows depends on the lactational stage. PLoS One 10:e0121956. https://doi.org/10.1371/journal.pone.0121956.

Hegardt, F. G. 1999. Mitochondrial 3-hydrocy-3-methylglutaryl-CoA synthase: A control enzyme in ketogenesis. Biochem. J. 338:569582.

Herrick, K. J., A. R. Hippen, K. F. Kalscheur, D. J. Schingoethe, S. D. Ranathunga, J. L. Anderson, S. C. Moreland, and J. E. van Eys. 2018. Infusion of butyrate affects plasma glucose, butyrate, and $\beta$-hydroxybutyrate but not plasma insulin in lactating dairy cows. J. Dairy Sci. 101:3524-3536. https://doi.org/10.3168/jds .2017-13842.

Johnston, C., and T. J. DeVries. 2018. Short communication: Associations of feeding behavior and milk production in dairy cows. J. Dairy Sci. 101:3367-3373. https://doi.org/10.3168/jds.2017-13743.

Kelton, D. F., K. D. Lissemore, and R. E. Martin. 1998. Recommendations for recording and calculating the incidence of selected clinical diseases of dairy cattle. J. Dairy Sci. 81:2502-2509. https://doi .org/10.3168/jds.S0022-0302(98)70142-0.

Kessler, E. C., J. J. Gross, R. M. Bruckmaier, and C. Albrecht. 2014 Cholesterol metabolism, transport, and hepatic regulation in dairy cows during transition and early lactation. J. Dairy Sci. 97:54815490. https://doi.org/10.3168/jds.2014-7926.

Li, S., I. Yoon, M. Scott, E. Khafipour, and J. C. Plaizier. 2016. Impact of Saccharomyces cerevisiae fermentation product and subacute ruminal acidosis on production, inflammation, and fermentation in the rumen and hindgut of dairy cows. Anim. Feed Sci. Technol. 211:50-60.

Loor, J. J., R. E. Everts, M. Bionaz, H. M. Dann, D. E. Morin, R. Oliveira, S. L. Rodriguez-Zas, J. K. Drackley, and H. A. Lewin. 2007. Nutrition-induced ketosis alters metabolic and signaling gene networks in liver of periparturient dairy cows. Physiol. Genomics 32:105-116. https://doi.org/10.1152/physiolgenomics.00188.2007.

Middleton, E., C. Kandaswami, and T. C. Theoharides. 2000. The effects of plant flavonoids on mammalian cells: Implications for inflammation, heart disease, and cancer. Pharmacol. Rev. 52:673751.

Mullins, C. R., L. K. Mamedova, M. J. Brouk, C. E. Moore, H. B Green, K. L. Perfield, J. F. Smith, J. P. Harner, and B. J. Bradford. 2012. Effects of monensin on metabolic parameters, feeding behavior, and productivity of transition dairy cows. J. Dairy Sci. 95:1323-1336. https://doi.org/10.3168/jds.2011-4744.

Mullins, C. R., L. K. Mamedova, A. J. Carpenter, Y. Ying, M. S. Allen, I. Yoon, and B. J. Bradford. 2013. Analysis of rumen microbial populations in lactating dairy cattle fed diets varying in carbohydrate profiles and Saccharomyces cerevisiae fermentation product. J. Dairy Sci. 96:5872-5881. https://doi.org/10.3168/jds .2013-6775.

National Research Council (NRC). 2001. Nutrient Requirements of Dairy Cattle. 7th rev. ed. Natl. Acad. Sci., Washington, DC.

Olagaray, K. E., S. E. Sivinski, B. A. Saylor, L. K. Mamedova, J. A. Sauls, I. Yoon, and B. J. Bradford. 2019. Impact of Saccharomyces cerevisiae fermentation product on feed intake parameters, lactation performance, and metabolism of transition dairy cattle Kansas Agric. Exp. Stat. Res. Rep. 4. https://doi.org/10.4148/ 2378-5977.7711

Ospina, P. A., D. V. Nydam, T. Stokol, and T. R. Overton. 2010. Evaluation of nonesterified fatty acids and $\beta$-hydroxybutyrate in transition dairy cattle in the northeastern United States: Critical thresholds for prediction of clinical diseases. J. Dairy Sci. 93:546554. https://doi.org/10.3168/jds.2009-2277.

Penner, G. B., K. A. Beauchemin, and T. Mutsvangwa. 2007. Severity of ruminal acidosis in primiparous Holstein cows during the periparturient period. J. Dairy Sci. 90:365-375. https://doi.org/10 .3168/jds.S0022-0302(07)72638-3.

Penner, G. B., M. A. Steele, J. R. Aschenbach, and B. W. Mcbride. 2014. Ruminant Nutrition Symposium: Molecular adaptation of ruminal epithelia to highly fermentable diets. J. Anim. Sci 89:1108-1119. https://doi.org/10.2527/jas.2010-3378.

Pfaffl, M. W. 2001. A new mathematical model for relative quantification in real-time RT-PCR. Nucleic Acids Res. 29:e45.

Piva, G., S. Belladonna, G. Fusconi, and F. Sicbaldi. 1993. Effects of yeast on dairy cow performance, ruminal fermentation, blood components, and milk manufacturing properties. J. Dairy Sci. 76:27172722. https://doi.org/10.3168/jds.S0022-0302(93)77608-0.

Poppy, G. D., A. R. Rabiee, I. J. Lean, W. K. Sanchez, K. L. Dorton, and P. S. Morley. 2012. A meta-analysis of the effects of feeding yeast culture produced by anaerobic fermentation of Saccharomyces cerevisiae on milk production of lactating dairy cows. J. Dairy Sci. 95:6027-6041. https://doi.org/10.3168/jds.2012-5577.

Quant, P. A., P. K. Tubbs, and M. D. Brand. 1990. Glucagon activates mitochondrial 3-hydroxy-3-methylglutaryl-CoA synthase in vivo by decreasing the extent of succinylation of the enzyme. Eur. J. Biochem. 187:169-174.

Ramsing, E. M., J. A. Davidson, P. D. French, I. Yoon, M. Keller, and H. Peters-Fleckenstein. 2009. Effects of yeast culture on peripartum intake and milk production of primiparous and multiparous Holstein cows. Prof. Anim. Sci. 25:487-495.

Rathbun, F. M., R. S. Pralle, S. J. Bertics, L. E. Armentano, K. Cho, C. Do, K. A. Weigel, and H. M. White. 2017. Relationships between body condition score change, prior mid-lactation phenotypic residual feed intake, and hyperketonemia onset in transition dairy cows. J. Dairy Sci. 100:3685-3696. https://doi.org/10.3168/ jds.2016-12085.

Robinson, P. H., and L. J. Erasmus. 2009. Effects of analyzable diet components on responses of lactating dairy cows to Saccharomyces cerevisiae based yeast products: A systematic review of the literature. Anim. Feed Sci. Technol. 149:185-198. https://doi.org/10 $.1016 /$ j.anifeedsci.2008.10.003.

Schingoethe, D. J., K. N. Linke, K. F. Kalscheur, A. R. Hippen, D. R. Rennich, and I. Yoon. 2004. Feed efficiency of mid-lactation dairy cows fed yeast culture during summer. J. Dairy Sci. 87:4178-4181. https://doi.org/10.3168/jds.S0022-0302(04)73561-4.

Schlegel, G., R. Ringseis, J. Keller, F. J. Schwarz, and K. Eder. 2012 Changes in the expression of hepatic genes involved in cholesterol homeostasis in dairy cows in the transition period and at different stages of lactation. J. Dairy Sci. 95:3826-3836. https://doi.org/10 $.3168 /$ jds.2011-5221.

Schukken, Y. H., D. J. Wilson, F. Welcome, L. Garrison-Tikofsky, and R. N. Gonzalez. 2003. Monitoring udder health and milk quality using somatic cell counts. Vet. Res. 34:579-596. https://doi.org/10 .1051/vetres:2003028.

Shen, Y., H. Wang, T. Ran, I. Yoon, A. M. Saleem, and W. Yang. 2018. Influence of yeast culture and feed antibiotics on ruminal fermentation and site and extent of digestion in beef heifers fed high grain rations. J. Anim. Sci. 96:3916-3927. https://doi.org/10 $.1093 /$ jas $/$ sky249.

Shi, W., C. E. Knoblock, K. V. Murphy, T. C. Bruinjé, I. Yoon, D J. Ambrose, and M. Oba. 2019. Effects of supplementing a Saccharomyces cerevisiae fermentation product during periparturient period on performance of dairy cows fed fresh diets differing in starch content. J. Dairy Sci. 102:3082-3096.

Sutton, J. D., M. S. Dhanoa, S. V. Morant, J. France, D. J. Napper, and E. Schuller. 2003. Rates of production of acetate, propionate, 
and butyrate in the rumen of lactating dairy cows given normal and low-roughage diets. J. Dairy Sci. 86:3620-3633. https://doi .org/10.3168/jds.S0022-0302(03)73968-X.

Urrutia, N., Y. Ying, and K. J. Harvatine. 2017. The effect of conjugated linoleic acid, acetate, and their interaction on adipose tissue lipid metabolism in nonlactating cows. J. Dairy Sci. 100:50585067. https://doi.org/10.3168/jds.2016-12232.

Urrutia, N. L., and K. J. Harvatine. 2017. Acetate dose-dependently stimulates milk fat synthesis in lactating dairy cows. J. Nutr. 147:763-769. https://doi.org/10.3945/jn.116.245001.

van Dorland, H. A., M. Graber, S. Kohler, A. Steiner, and R. M. Bruckmaier. 2014. Comparison of hepatic adaptation in extreme metabolic phenotypes observed in early lactation dairy cows onfarm. J. Anim. Physiol. Anim. Nutr. (Berl.) 98:693-703. https:// doi.org/10.1111/jpn.12125.

van Dorland, H. A., S. Richter, I. Morel, M. G. Doherr, N. Castro, and R. M. Bruckmaier. 2009. Variation in hepatic regulation of metabolism during the dry period and in early lactation in dairy cows. J. Dairy Sci. 92:1924-1940. https://doi.org/10.3168/jds.2008-1454.

Van Soest, P. J. V. A. N., J. B. Robertson, and B. A. Lewis. 1991. Methods for dietary fiber, neutral detergent fiber, and nonstarch polysaccharides in relation to animal nutrition. J. Dairy Sci. 74:3583-3597. https://doi.org/10.3168/jds.S0022-0302(91)78551 -2 .

Vanholder, T., J. Papen, R. Bemers, G. Vertenten, and A. C. B. Berge. 2015. Risk factors for subclinical and clinical ketosis and association with production parameters in dairy cows in the Netherlands. J. Dairy Sci. 98:880-888. https://doi.org/10.3168/jds.2014-8362.

Vaughan, A. M., and J. F. Oram. 2006. ABCA1 and ABCG1 or ABCG4 act sequentially to remove cellular cholesterol and generate cholesterol-rich HDL. J. Lipid Res. 47:2433-2443. https://doi .org/10.1194/jlr.M600218-JLR200.

Weber, C., C. Hametner, A. Tuchscherer, B. Losand, E. Kanitz, W. Otten, S. P. Singh, and R. M. Bruckmaier. 2013. Variation in fat mobilization during early lactation differently affects feed intake, body condition, and lipid and glucose metabolism in high-yielding dairy cows. J. Dairy Sci. 96:165-180. https://doi.org/10.3168/jds $2012-5574$.

Wiedmeier, R. D., M. J. Arambel, and J. L. Walters. 1987. Effect of yeast culture and Aspergillus oryzae fermentation extract on ruminal characteristics and nutrient digestibility. J. Dairy Sci. 70:20632068. https://doi.org/10.3168/jds.S0022-0302(87)80254-0.

Yalcin, S., S. Yalcin, P. Can, A. O. Gurdal, C. Bagci, and O. Eltan. 2011. The nutritive value of live yeast culture (Saccharomyces cerevisiae) and its effect on milk yield, milk composition and some blood parameters of dairy cows. Asian-australas. J. Anim. Sci. 24:1377-1385. https://doi.org/10.5713/ajas.2011.11060.

Yuan, K., J. K. Farney, L. K. Mamedova, L. M. Sordillo, and B. J. Bradford. 2013. TNFa altered inflammatory responses, impaired health and productivity, but did not affect glucose or lipid metabolism in early-lactation dairy cows. PLoS One 8:e80316. https://doi .org/10.1371/journal.pone.0080316.

Yuan, K., T. Liang, M. B. Muckey, L. G. D. Mendonça, L. E. Hulbert, C. C. Elrod, and B. J. Bradford. 2015a. Yeast product supplementation modulated feeding behavior and metabolism in transition dairy cows. J. Dairy Sci. 98:532-540. https://doi.org/10.3168/jds .2014-8468.

Yuan, K., L. G. D. Mendonça, L. E. Hulbert, L. K. Mamedova, M. B. Muckey, Y. Shen, C. C. Elrod, and B. J. Bradford. 2015b. Yeast product supplementation modulated humoral and mucosal immunity and uterine inflammatory signals in transition dairy cows. J. Dairy Sci. 98:3236-3246. https://doi.org/10.3168/jds.2014-8469.

Zarrin, M., L. De Matteis, M. C. M. B. Vernay, O. Wellnitz, H. A. van Dorland, and R. M. Bruckmaier. 2013. Long-term elevation of 3-hydroxybutyrate in dairy cows through infusion: Effects on feed intake, milk production, and metabolism. J. Dairy Sci. 96:29602972. https://doi.org/10.3168/jds.2012-6224.

Zaworski, E. M., N. A. Fadden, W. K. Sanchez, I. Yoon, and G. Bobe. 2014. Effects of feeding various dosages of Saccharomyces cerevisiae fermentation product in transition dairy cows. J. Dairy Sci. 97:3081-3098. https://doi.org/10.3168/jds.2013-7692. 